\title{
SIK DOMONKOS
}

TÁRSADALMI PATOLÓGIA ÉS PSZICHOPATOLÓGIA

A PSZICHOLÓGIAI DIAGNÓZISOK ÉS TERÁPIÁK HASZNA A KRITIKAI ELMÉLET SZÁMÁRA

DOI: 10.18030/socio.hu.2015.3.197

\section{ABSZTRAKT}

A tanulmány célja egy a szenvedés tapasztalatából kiinduló kritikai elmélet programjának felvázolása. A szenvedés szisztematikus formában a terápiás tekintet számára tárul fel, ezért a szenvedés határállapotainak pszichiátriai és pszichológiai leírásából indulok ki. Első lépésben azokat a társadalmi formákat igyekszem azonosítani, melyek a cselekvési képesség megakadásának - pszichopatológiaként azonosított - különböző mintázataival összefüggésbe hozhatók. Második lépésben pedig azokat, melyek a megakadt cselekvési képesség kezelésének - pszichoterápiaként azonosított - gyakorlatait imitálják a hétköznapi életben. Az első lépést a kényszerbetegség elemzésének, a másodikat a kognitív terápia újraértelmezésének példáján mutatom be. A különböző társadalmi formák értelmezésekor Bourdieu, Giddens, Habermas, Honneth és Lash elméleteinek - korábban bemutatott - hálózatelméleti szintéziséből indulok ki.

Kulcsszavak: kritikai elmélet, pszichopatológia

\section{ABSTRACT}

The paper aims at outlining a critical theory grounded on the level of the experience of suffering. As suffering is analysed in a systematic way by therapeutic approaches, psychiatric and psychological descriptions of various forms of suffering are used as a theoretical starting point. Firstly forms of socialization that explain psychopathologies understood as idealtypes of losing one's capability of acting are identified. Secondly forms introducing psychotherapies that is the praxis oriented to correct psychopathologies are identified. The example used in the first case is obsessive-compulsive disorder, and cognitive therapy in the second case. In order to conceptualise forms of socialization, a previously elaborated network model of the theories of Bourdieu, Giddens, Habermas, Honneth and Lash is applied.

Keywords: critical theory, psychopathology 


\section{SIK DOMONKOS}

\section{TÁRSADALMI PATOLÓGIA ÉS PSZICHOPATOLÓGIA}

A pszichológiai diagnózisok és terápiák haszna a kritikai elmélet számára ${ }^{1}$

\section{BEVEZETÉs}

A tág értelemben vett kritikai elméletek normatív bázisának alapjául a társadalmi eredetű emberi szenvedés különböző formái szolgálnak: az elidegenedés (Marx), az értelemvesztés (Weber), az anómia (Durkheim), az egyenlőtlenség tapasztalata (Bourdieu), az ontológiai biztonság hiánya és az identitáskonstrukció nehézségei (Giddens), a hatalmi szó által torzított kommunikáció (Habermas), az információs társadalom nivelláló hatása (Lash), vagy az elismerés különböző formáinak hiánya (Honneth). A társas viszonyokra visszavezethető szenvedés kitüntetett szerepe abból fakad, hogy hidat képez a társadalmi patológiák fenomenológiai és strukturális szintje között: az nem más, mint az egyéni cselekvő által megélt társadalmi zavar. ${ }^{2}$ Ebben az értelemben azokra a problémákra utal, melyek nem csupán a megfigyelő számára mutatkoznak meg igazságtalanságként, önkényként vagy elnyomásként, hanem egyúttal az egyén számára is megtapasztalhatóak egy nehéz vagy elviselhetetlen élet formájában. A szenvedésből kiinduló kritika ilyenformán fenomenológiailag motivált: nem elégszik meg a strukturális viszonyok absztrakt bírálatával, hanem azon patológiákra fókuszál, melyeket maguk a cselekvők átélnek.

Noha ezek a kritikai elméletek a társadalmi eredetű szenvedések különböző formáira utalnak, magukat a szenvedéseket korántsem önmagukban szemlélik. Ehelyett egy-egy explicit vagy hallgatólagos társadalomelméleti vagy filozófiai antropológiai értelmezési keretre támaszkodnak: a termelési eszközökhöz való viszonya révén meghatározott (Marx), az instrumentális racionalitás által vezérelt (Weber), a mechanikus és organikus szolidaritás révén integrált (Durkheim), az elleplezett egyenlőtlenségek által formált habitus szerint cselekvő (Bourdieu), a tudattalan motivációk és reflexivitás által meghatározott (Giddens), kommunikatívan és rendszerszerűen integrált (Habermas), az esztétikai reflexivitás és az információs hálózat között bolyongó (Lash), illetve az elismerés különböző formáiért küzdő (Honneth) ember képéből indulnak ki. A társadalmi eredetű szenvedésekhez ilyenformán származtatott fogalomként férnek hozzá: a különböző társadalmi integrációs vagy antropológiai sajátosságokból következő igények torzulásaként vagy ellehetetlenüléseként értelmezve őket.

Ezzel a - legjelentősebb kritikai elméleteket egyaránt jellemző - elméletstratégiával kapcsolatban ugyanakkor megfogalmazható egy alapvető kritika. Minthogy a normatív bázisként szolgáló szenvedést nem empirikusan, hanem egy - többnyire univerzálisnak szánt - elméleti konstrukcióból vezeti le, így teljességgel esetleges

1 Köszönöm névtelen bírálóimnak és Zakariás Ildikónak a kézirat első változásához füzött megjegyzéseket, melyek sokat segítettek az esetleges félreértések tisztázásában.

2 A kései Adorno szavaival: „A szükséglet, hogy hangot adjunk a szenvedésnek, ez minden igazság előfeltétele. A szenvedés ugyanis nem más mint maga az objektivitás, abban a formában ahogy a szubjektumra terhelődik." (1973: 17-18) 
marad, hogy egy adott elmélet a lehetséges szenvedések közül melyekhez fér hozzá, és melyek maradnak látóterén kívül. Abból fakadóan, hogy a lehetséges szenvedéseknek csupán egy leszúkített körével dolgoznak, a fenti elméletek kritikai potenciálja egyfelől korlátozott marad: azáltal, hogy a társadalmi eredetű szenvedés egy-egy formáját állítják középpontba, egyúttal figyelmen kívül hagyják annak egyéb formáit. Másfelől, így fennáll a veszélye annak is, hogy nem figyelnek fel a - fókuszba állított szenvedéstípus szempontjából emancipatórikusnak tűnő jelenségek - a figyelmen kívül hagyott szenvedéstípusok perspektívájából - potenciálisan patologikus mivoltára.

A kritikai elméletek e fundamentális problémáját csakis a társadalomelméleti, filozófiai antropológiai megalapozás helyettesítésével lehet kiküszöbölni. Ahelyett, hogy a társadalmi integráció torzulásait a szenvedés elméletileg beszúkített fogalmaiból vezetnénk le, vissza kell térni magához a szenvedésre történő reflexióhoz, és ebből következtetni a társadalmi patológiákra. A szenvedés különböző formáit elsősorban azok a tudományok és praxisok állítják fókuszba, melyek célja azok enyhítése és megszüntetése, s amelyek így - cselekvők számára problematikussá váló élethelyzetek legkülönbözőbb formáival kerülve kapcsolatba -, a lehetséges szenvedések olyan empirikus leírásait dolgozzák ki, amiben maga a szenvedő is kifejezheti önmagát, potenciálisan felülírva az előzetesen adott értelmezési kereteket. Amennyiben a szenvedések empirikus valóságából szeretnénk kiindulni a kritikai elméletek megalapozásakor, azokhoz a tapasztalatokhoz fordulhatunk, melyek egy ilyen értelemben vett terápiás megismerésérdeken alapulnak. ${ }^{3} \mathrm{~A}$ terápiás tekintet számára a szenvedéstörténetek azon végpontjai hozzáférhetők, amikor az egyén már nem képes a probléma önálló megoldására, és segítségre szorul. Ebben az értelemben a terápiás tekintet a szenvedés kiteljesedett, önmagától nem múló formáival kerül kapcsolatba. Ezeket vizsgálva próbál visszakövetkeztetni azokra az okokra, melyek kialakulásukért és kiteljesedésükért felelősek.

A kritikai elméletek számára természetesen a szenvedéseknek csupán egy korlátozott köre releváns: azok, amelyek valamilyen módon a társas viszonyokhoz köthetőek, vagyis ahhoz, hogy az egyén milyen strukturális pozíciót tölt be, milyen világértelmezésekhez fér hozzá, és milyen viszonyban van az őt körülvevőkkel. A kérdés tehát ezen a ponton az, hogy a szenvedés lehetséges végpontjait empirikusan feltáró terápiás pillantás eredményei közül melyek azok, amelyek egy kritikai elmélet számára hasznosíthatóak? Egyfajta orvosi tekintet perspektívájából az ember puszta biológiai entitásként értelmezhető, melynek múködését általános természettörvények határozzák meg. Ebben a megközelítésben az ember - biológiai-kémiai-fizikai egységként felfogott - testre redukálódik, a cselekvési és reflexiós képesség pedig irrelevánssá válik. Az ebből a perspektívából feltáruló szenvedések a kritikai elméletek szempontjából pusztán abban a korlátozott értelemben relevánsak, hogy a strukturális pozícióból magyarázhatók bizonyos rendellenességek kialakulásának és kezelhetőségének valószínűségei. E megközelítés amellett, hogy a társadalmi egyenlőtlenségek kritikájának kiemelt fontosságú terepére utal, a kritikai elmélet megalapozásának szempontjából kevéssé termékeny.

Ahhoz, hogy elméleti értelemben releváns empirikus megfigyelésekhez jussunk, a terápiás tekintet azon specifikus formáira kell fókuszálnunk, amelyek az embert nem csupán biológiai egységként kezelik, hanem

3 Hasonló irányba tapogatózott a Megismerés és érdekben Habermas is (2005), a pszichoanalízisből próbálva kibontani a társadalomkritika lehetőségét. Ez a törekvés ugyanakkor korlátozott maradt amiatt, hogy csupán a terápia gyakorlatára fókuszált, figyelmen kívül hagyva a terápiás úton születő ismereteket. 
önálló cselekvésre képes ágensként is. Ezek a cselekvési képességében megzavart egyénre irányuló pszichiátriai és pszichológiai diagnózisok. A viselkedés zavarait leíró pszichiátriai és pszichológiai megfigyelések, abból fakadóan, hogy a biológiai szint mellett feltételeznek egy intencionálisan vagy diszpozicionálisan szerveződő autonóm cselekvési szintet, olyan kapcsolódási felületet kínálnak a kritikai társadalomelméletek számára, ami - szemben a szenvedés biológiai formáival - túlmutat a strukturális pozícióhoz köthető egyenlőtlenségek kritikáján. A szándékok és nem-tudatosuló beidegződések ugyanis biológiai aspektusuk mellett a társadalmi térben is formálódnak. Minthogy a cselekvési képesség alakulására a biológiai tényezők mellett a társas viszonyok is hatást gyakorolnak, ezért az - intencionális vagy diszpozicionális - cselekvés zavarai is óhatatlanul összefüggésben állnak a társas viszonyok zavaraival. ${ }^{4}$

Ez a következtetés teremt lehetőséget arra, hogy a társadalomkritikát közvetlenül a szenvedés empirikusan megfigyelhető formáiból kiindulva alapozzuk meg. A pszichopatológiák pszichiátriai és pszichológiai leírásai a szenvedés olyan végső stádiumait tárják fel, melyben a cselekvési képesség oly mértékben korlátozódik, hogy az egyéni és társas cselekvések ellehetetlenülnek. Ebben az értelemben a pszichopatológia azon formái, melyekkel a pszichiátriai és pszichológiai tekintet találkozik, a szenvedés olyan határállapotaira utalnak, amiben az egyén elveszti az uralmat cselekedetei felett, és képtelenné válik helyzete megváltoztatására. Minthogy a cselekvési képesség beszúkülése és torzulása egy patologikus társadalmi kontextust is feltételez, ezért - a biológiai tényezők mellett - minden pszichopatológia esetében rekonstruálható egy a torzulás kialakulását és fenntartását valószínűsitő szocializációs pálya is. A pszichopatológiák ebben az értelemben a társadalmi okokra is visszavezethető szenvedés végső stádiumait fejezik ki, a társas viszonyok olyan konfigurációjának való tartós kitettséget, amiben a világ értelmezésének és a szokásoknak egy, az egyéni és társas cselekvések végrehajtásában egyaránt fennakadást okozó mintázata alakul ki. A pszichopatológiákkal küzdő egyén annak a társadalmi konstellációnak a következményeit hordja ki, amely nem teszi lehetővé vagy ellehetetleníti az önálló cselekvést.

A cselekvési képesség zavarainak e társadalmi dimenziója révén értelmezhetők újra a kritikai elmélet keretei között a pszichopatológiák terápiás megismerésérdekú leírásai. A viselkedési zavarok pszichiátriai és pszichológiai diagnózisai olyan ideáltípusoknak tekinthetők, melyek a cselekvési képesség beszűkülésének különböző határállapotait azonosítják. Amennyiben ezeket a kritikai elméletek perspektívájából újraértelmezzük, úgy lehetőség nyílik azoknak a szocializációs konfigurációknak az azonositására, melyekben vagy nincs tere a cselekvési képesség felfüggesztését eredményező szenvedések kezelésének, vagy egyenesen azok állandósulása valószínűsíthető. A kritikai elméletek megalapozásához ennek megfelelően azokat az integrációs formákat kell rekonstruálni, melyek, ha nem is feltétlenül kiváltó okai a cselekvési képesség különböző zavarainak, de - ellensúlyozásukra képtelen interakciós közegként - közvetve mégiscsak előfeltételei kiteljesedésüknek és sta-

4 Ezen a ponton érdemes hangsúlyozni, hogy a kortárs pszichológiában, pszichiátriában is egyre inkább teret nyer a biológiai, pszichodinamikus, kognitív-behaviorista és szociokulturális megközelítések párhuzamos alkalmazása (Comer 2010: 49-70). Egy ilyen összetett megközelítés legfontosabb sajátossága, hogy a különböző tényezők interakciójaként magyarázza a pszichopatológiák kialakulását. Ez egyúttal azt is jelenti, hogy a társadalmi patológiák hiánya korántsem garancia a pszichopatológiáktól való mentességre, ez csupán egy komponens a többi mellett (melynek jelentőségét az abból fakadó morális tét adja, hogy a szenvedések társadalmilag kezelhető dimenziójára utal). Az alábbi vizsgálódások is ebbe a keretbe illeszthetők abban az értelemben, hogy nem a pszichopatológiák szociológiai redukciójára törekszenek, hanem sokkal inkább a társadalmi komponens alaposabb megértésére. 
bilizálódásuknak. Minthogy az ilyen integrációs formáknak való tartós kitettség az önálló cselekvési képesség elvesztéséhez és tartós szenvedéshez vezet, így e formák egyúttal a szenvedés közvetlen tapasztalatából kiinduló kritikai elmélet normatív bázisát is körvonalazzák. A szenvedés végső stádiumát valószínűsítő integrációs formákból kiindulva a szenvedés kevésbé szélsőséges variánsainak társadalmi előfeltételeire is visszakövetkeztethetünk. Így ezen integrációs formák azonosítása révén nem csupán a szenvedés pszichopatológiákban kifejeződő határállapotai, hanem egyúttal a - hétköznapi életet nem ellehetetlenítő, csupán megnehezítő - kevésbé látványos variánsai is bevonhatók a kritikai elmélet látóterébe.

A társadalomtudományok történetében a pszichiátriai és pszichológiai tudáshoz való viszony - nem függetlenül attól, hogy a szociológiának részben ezekkel szemben kellett megalapoznia magát - a kezdetek óta elsősorban kritikai volt. Ahogy azt a leginkább kézzelfoghatóan talán Goffman (1974) és Foucault (2004) nagy hatású elemzései mutatják, a pszichiátriai és pszichológiai tudásra a kritikai elméletek elsősorban mint valami gyanús, leleplezendőre vagy éppen társadalomtudományosan megalapozandóra tekintettek. Következtetésük szerint, egyrészt a pszichiátriai diagnózisok maguk is konstitutív elemévé válnak a társas interakciók sorozatában újratermelődő identitásnak, ami a totális intézményekben a szelf - eredeti problémáktól független drasztikus átalakulását eredményezi. Ebben a kontextusban különösen veszélyes a pszichiátria és pszichológia medikalizáló hatása, vagyis az élethelyzet egészével összefüggő problémáknak - a cselekvő esszenciális tulajdonságaként felfogott - „betegségként” való átértelmezése. Másrészt, minthogy a terápiás megismerésérdek maga is adott társadalmi kontextusba ágyazódó kategóriák szerint észleli a viselkedési zavarok tüneteit és dolgozza ki diagnózisait, ezért egyáltalán nem esetleges az, hogy melyek azok a viselkedési mintázatok, amik egy adott társadalmi konstellációban patologikusnak minősülnek, hogy milyen okokkal magyarázzák ezek kialakulását, és hogy mindezzel összefüggésben milyen terápiákkal kísérleteznek. Harmadrészt, minthogy az egyéni sajátosságok formálódása értelmezhetetlen a társas interakciók nélkül, a pszichopatológiák magyarázata sem nélkülözheti a társas környezetre vonatkozó szociológiai reflexiót. Ezt azonban a pszichiátriai és pszichológiai megközelítés egyaránt figyelmen kívül hagyja, és elsősorban az egyén - tudati vagy biológiai - belső sajátosságaival magyarázza problémáit. Összességében a pszichiátriát és pszichológiát azáltal, hogy önmagát elsősorban természettudományos megalapozottságú objektiv, értékmentes tudásként látja, egy korántsem veszélytelen szcientista önfélreértés jellemzi: az önreflexió hiányában óhatatlanul a társadalmat jellemző egyenlőtlenségi viszonyok közvetítőjévé válik, létrehozva tudás és hatalom - „biohatalmi” logikát kifejező (Foucault 1999: 141) konglomerátumát.

Ugyanakkor ebből a jogos kritikából a társadalomtudományok számára egy sajátos bezárkózás is következett. A hatalomkritika által hiteltelenített pszichiátriai és pszichológiai tudás csak mint a bírálat tárgya jelenhetett meg a társadalomkritika horizontján, ami sajátos vakfolttal terhelte meg az elméletalkotást. ${ }^{5}$ Ahelyett,

5 A tekintetben a különböző megközelítések tág keretek között mozognak, hogy mennyire utasítják el a pszichiátriai tudást. Ennek egyik végpontján az antipszichiátriai mozgalom álláspontja áll, ami elfogadhatatlan és káros konstrukcióként tekint a pszichiátriai diagnózisokra és gyakorlatokra (Laing 1990, Szasz 2002). Másik végpontján állnak azok a megengedőbb megközelítések, melyek a pszichopatológiák medikalizáló, kizárólag betegségként való értelmezését utasítják vissza, és arra törekszenek az élettörténet egésze (Fernezely-Légmán 2003) vagy a közösségi kontextus (Bugarszki 2003, Stein-Santos 1998) felől közelítve, alternatív értelmezési keretet kínáljanak a pszichopatológiával élők és a nyilvánosság számára egyaránt. Az alábbiakban bemutatott gondolatmenet - noha teljesen más problémafelvetésból indul ki - ez utóbbiakhoz áll közelebb a tekintetben, hogy a pszichiátriai és pszichológiai tapasztalatok kritikája helyett azok - a társadalomkritikát potenciálisan megtermékenyítő - 
hogy a viselkedés zavarainak sajátos megismerésérdekú leírásaként a társadalomelméletek szisztematikusan feldolgozták volna a pszichiátria és pszichológia által előállított ismereteket, vagy csupán hallgatólagosan utaltak rájuk, vagy teljesen esetleges módon választottak ki egyeseket, miközben figyelmen kívül hagytak másokat. Az „elidegenedés”, „anómia”, „értelemvesztés”, „ontológiai bizonytalanság”, „elismerés-megvonás”, valamint az ezekhez hasonló konceptuális szerepet betöltő fogalmak egyaránt a korlátozott cselekvési képesség olyan esetleges metaforáinak tekinthetők, ami összefüggésbe hozható a pszichopatológiák empirikusan szisztematikusan megalapozott olyan fogalmaival mint a „generalizált szorongás”, „pánikbetegség”, „depresszió” vagy „kényszerbetegségek”. Ennek ellenére a kritikai elméletek - feltehetően a pszichiátriai és pszichológiai megismerésérdektől való idegenkedésükkel összefüggésben - csupán szórványosan vagy egyáltalán nem tettek kísérletet saját diagnózisaik és a pszichopatológiák kategóriáinak összekapcsolására. Ezáltal elmulasztották azt a lehetőséget, hogy a pszichiátriai és pszichológiai empirikus megfigyelésekben felhalmozódó tudást a kritikai elméletek számára hozzáférhetővé tegyék. Az alábbi tanulmányban e hiányból kiindulva azt igyekszem bemutatni, hogy miként profitálhat a kritikai elméletalkotás a szenvedés pszichiátriai és pszichológiai szempontokon alapuló leírásaiból.

Természetesen a pszichiátriai és pszichológiai tudás korántsem mentes az elméleti előfeltevésektől, és ebben az értelemben nem tekinthető a szenvedés értéksemleges elemzésének. Ráadásul az a fajta tudásszociológiai reflexivitás is kevésbé jellemzi, ami a társadalomtudományok sajátja. Ilyenformán úgy tekinthetünk rá, mint a cselekvési képesség zavarainak objektivista leírására. Mindebből következően a pszichiátriai és pszichológiai tudás nem használható fel közvetlenül, interpretációra szorul. A hétköznapi cselekvéseket és interakciókat ellehetetlenítő - és ennyiben a cselekvési képesség korlátozódásából fakadó szenvedés végső stádiumára utaló - tüneteknek, magyarázatoknak, valamint terápiás gyakorlatoknak a szisztematikus összegyújtése arra teremt lehetőséget, hogy a különböző társulási formák esetében feltegyük a kérdést, azok milyen variánsai járulhatnak hozzá adott probléma kialakulásához és fennmaradásához. Ebben az értelemben a pszichiátriai és pszichológiai tudás közvetve járul hozzá a kritikai elmélet megalapozásához: nem egy ahhoz képest adekvátabb megközelítést kínál, hanem lehetőséget teremt a szenvedést implikáló társulási formák azonosítására. Ilyenformán mindazok az episztemiológiai problémák, melyek magukkal a pszichiátriai és pszichológiai tudásokkal kapcsolatban felvethetők, jelen vizsgálódások szempontjából másodlagosnak tekinthetők.

Hasonlóan minden más tudományhoz, a pszichiátriai és pszichológiai tudás sem tekinthető egységesnek. A különböző megközelítések a pszichopatológiák okait és a lehetséges kezeléseket egyaránt eltérő oksági modellekben értelmezik. Minthogy az ezek közti differenciálást nem teszik lehetővé előzetes elméleti megfontolások, így az alábbiakban elsősorban a pszichiátria és pszichológia paradigmatikussá vált tudásbázisára támaszkodom, vagyis azokra a megfigyelésekre, amelyek egyrészt a diagnosztika alapjául szolgálnak (APA 2013), másrészt tankönyvi státuszra tettek szert (Comer 2010, Sharf 2012), és ebben az értelemben kiállták hosszú évtizedek falszifikációs próbáját. A patologikus társadalmi konstellációk leírásakor a korábbi munkáimban bemutatott hálózati társadalomelmélet (Sik 2012) kiterjesztett változatából (Sik 2014) indulok ki. Az alábbi tanulmányban elsőként ezt mutatom be röviden, majd ezt követően egy pszichopatológiai, valamint egy terápiás módszer hálózatelméleti rekonstrukciójára teszek kísérletet. 


\section{A KRITIKAI ELMÉLET HÁLÓZATI MODELLJE}

A kritikai elméletek olyan képviselői, mint Bourdieu, Giddens, Habermas, Honneth vagy Scott Lash a társadalmi integráció eltérő modelljei alapján tesznek kísérletet a modernitás emancipatorikus és patologikus tendenciáinak azonosítására. Az egyes integrációs modellek a társas cselekvéseket valószínűsítő mechanizmusokat azonosítanak és ennek megfelelően különböző problémákhoz férnek hozzá. A modernitás átfogó értelmezéséhez ilyenformán az integrációs mechanizmusok közös elméleti modellben történő egyesítése kínál lehetőséget. Ilyen, közös nevezőként szolgáló metaelméleti keret a tágabb hálózatelméleti diskurzus. Az olyan szerzők, mint Harrison White vagy Bruno Latour személyek és dolgok kapcsolódásaként írják le a társas cselekvéshelyzeteket, mely hálózatokon belül az összekapcsolódások és blokkolások mintázata a meghatározó. A társas cselekvések koordinációját biztosító különböző mechanizmusok ebben az értelmezési keretben a kapcsolódások és blokkolások ideáltipikus logikájaként értelmezhetők újra. A kapcsolódások és blokkolások logikáit attól függően, hogy a cselekvők számára is tudatosuló szándékként, tudatalatti motivációként vagy a cselekvések nem szándékolt következményeként újratermelődő struktúraként hatnak, intencionális, preintencionális és posztintencionális szinten értelmezhetjük (Sik 2012: 248-267). Ennek megfelelően az alábbi hálózati típusok azonosíthatók:

\section{1. ábra: A társadalmi hálózatok lehetséges szervezőelvei}

\begin{tabular}{|l|l|l|l|}
\hline & preintencionális & intencionális & posztintencionális \\
\hline Bourdieu & habitus & illúzió & mező \\
\hline Giddens & rutinok & kognitív reflexivitás & reflexív intézmény \\
\hline Habermas & életvilág & kommunikatív racionalitás & alrendszer \\
\hline Honneth & szeretet, intimitás & teljesítmény elismerése/ szolidaritás & jogi elismerés \\
\hline Lash & információ & esztétikai reflexivitás & technikai-tárgyi környezet \\
\hline
\end{tabular}

A társas cselekvéshelyzeteket hálózatokként értelmezve feltehető a kérdés, hogy a bennük részt vevő személyek és dolgok milyen kötésekkel kapcsolódnak egymáshoz. Ebből a perspektívából tetszőleges cselekvéshelyzet felbontható az érintett cselekvők és környezetük különböző típusú kötések révén szerveződő hálózataira. Így ahelyett, hogy a társas cselekvések valószínúségét különböző - egymást kizáró - mechanizmusokra vezetnénk vissza, és ezáltal beszúkítenénk a modernitás emancipatorikus és patologikus tendenciáinak értelmezési terét, egy átfogó szemléleti kerethez jutunk (Sik 2015a).

A társadalmi hálózatok kapcsolódási és blokkolási logikáját egyrészt a materiális és szimbolikus tőkék mentén szerveződő mezők, az azok működését a cselekvési motivációk szintjén szabályozó illúziók, valamint a cselekvési aspirációkat és stratégiákat testivé tett diszpozíciók szintjén keretező habitus határozza meg (Bourdieu 2002). Másrészt, a kötések igazodhatnak az ontológiai biztonságot szavatoló rutinok, a késő modernitás kihívásaival való megküzdéshez nélkülözhetetlen egyéni és intézményi reflexivitás logikájához is (Giddens 1984, 1991). Harmadrészt, a hálózatokat megszervezheti a valóság értelmezésének magától értetődő interszubjektív horizontjaként funkcionáló életvilág, az annak újratermelődési mechanizmusaként felfogott kommunikatív cselekvés vagy a mindezek komplementereként felfogott, médiumok mentén szerveződő, rendszerszerű kommunikáció (Habermas 2011). Negyedrészt a kapcsolódás és blokkolás logikáját meghatározhatják az elismerés különböző formái, az intimitáson alapuló szeretet, az egyéni teljesítmény megbecsülése és a különböző életformákra vonatkozó szolidaritás és az univerzális méltóság jogi elismerése (Honneth 2013). Végül a társadalmi 
hálózatok ráépülhetnek a narratív értelemképződés helyére lépő információ folyamatos áramlásának logikájára, az osztályozáson és sémákon alapuló valóságértelmezéstől független esztétikai reflexivitásra, vagy az osztályozás logikáját materiális szinten megjelenítő technikai-tárgyi környezetre is (Lash 1999, 2002).

E hálózati típusok a késő modernitásban potenciálisan előforduló mikro és makro szintű társadalomszerveződési formákat írnak le, ha nem is a teljesség igényével, de az elméleti szempontból legrelevánsabb koncepciókat lefedve. A különböző típusú kötések által meghatározott társadalmi hálózatok eltérő logika szerint szerveződő társadalmi szféraként értelmezhetők, melyek saját szokásokkal, szemantikákkal, játékszabályokkal, nyelvjátékokkal és kényszerekkel jellemezhetők. Az interakciók révén e társadalmi terek kölcsönhatásban állnak egymással, ami azt jelenti, hogy egyazon cselekvéshelyzeten belül több hálózati logika is kifejtheti hatását, potenciálisan felerősítve vagy gyengítve egymást (Sik 2014). A késő modern egyén társas környezetét egy ilyen értelemben vett komplex hálózat alkotja, melynek különböző szeletei válnak relevánssá az egyes cselekvéshelyzetekben.

A pszichopatológiák és terápiák társadalomelméleti újraértelmezéséhez ez az általános keret oly módon szolgálhat kiindulópontként, hogy feltárja a társakhoz kapcsolódás különböző dimenzióit. E dimenziók mentén, a különböző hálózatok torzulásaira utalva egyrészt jellemezhetővé válik az a szocializációs pálya, melynek eredményeként a cselekvési képesség olyannyira beszúkül, hogy az egyéni és társas cselekvések ellehetetlenülnek. A szenvedés pszichopatológiákban kifejeződő végső stádiumaiból ilyenformán visszakövetkeztethetünk a társadalmasulás azon patologikus formáira, melyek valószínúsítik kialakulásukat és fennmaradásukat. Másrészt a különböző hálózati típusok segítségével jellemezhető az a korrekciós forgatókönyv is, ami a pszichopatológiák formáját öltő szenvedés enyhítését valószínúsíti. A pszichoterápiák társadalomelméleti újraértelmezése révén megragadhatóvá válnak azok a hálózati konfigurációk, melyek a hétköznapi cselekvéshelyzetekben imitálva a terápiás folyamatokat, reszocializációs hatást fejtenek ki. A továbbiakban egy-egy ilyen példát mutatok be.

\section{KÉNYSZERBETEGSÉGEK}

A különböző formát öltő obszesszív gondolatok és kényszeres cselekvések közös sajátossága, hogy az egyén kiszolgáltatottá válik a rá törő belső késztetéseknek, és képtelen tetteit uralni. A kényszeres gondolatok és viselkedésformák adott cselekvéshelyzet társas-pragmatikus szempontjait felülírva megakasztják a cselekvést. Ha ezek helyett az egyén mégis a cselekvéshelyzet társas-pragmatikus szempontjaihoz próbál igazodni, belső feszültséget él át. Annak ellenére, hogy a kényszeres kívánságokkal, fantáziákkal és gondolatokkal adott esetben nem tud azonosulni, mégis képtelen figyelmen kívül hagyni őket, még úgy is, hogy irracionális mivoltuknak esetleg tudatában van. Az olyan kényszeres szokások, mint a kontroll- vagy tisztaságmánia foglyul ejtik az egyént, aki megmagyarázhatatlan rettegést érez aprólékosan kidolgozott rítusai elmulasztása esetén (APA 2013: 235-265). Azt, hogy az ellenállhatatlan belső késztetések pontosan minek következtében alakulnak ki, továbbá, hogy milyen viselkedésformákhoz vezetnek, a különböző megközelítések eltérő modellekkel magyarázzák. Így csakis ezek tisztázását követően nyilik lehetőség azoknak a társadalmi hálózatoknak a jellemzésére, melyek e zavarok fenntartásához hozzájárulnak. 
A pszichoanalitikus magyarázatok szerint kényszerbetegségek akkor alakulnak ki, ha az egyén megriad „Ösztönénje” impulzusaitól és azokat akár izolálva, akár szimbolikusan meg nem történtté téve, akár ellentétes irányú cselekvésekkel ellensúlyozva igyekszik elhárítani. A saját tudatalatti késztetésektől való elidegenedés a korai kapcsolatok zavaraival hozható összefüggésbe. A rideg és követelő szülők gyermekei impulzusaikkal kizárólag mint valami normatíve elfogadhatatlannal és megzabolázandóval találkoznak. Ennek hatására az egyén olyan fokú szégyent és bűntudatot él át, melyet csakis kényszeres elkerüléssel vagy irracionális - „mágikus” rítusokkal képes semlegesíteni (Comer 2010: 151-152). A behaviorista magyarázat szerint a kényszeres viselkedésformák kondicionálás során alakulnak ki: az olyan eredetileg jelentésnélküli cselekvések, mint a kézmosás, abban az esetben, ha rendszeresen hozzákapcsolódnak valamilyen szorongásra okot adó jelenség elmúlásához, önálló jelentésre tesznek szert. A szorongás elmúlásának kísérőjelenségéből az egyén számára a szorongást megszüntető okká válnak. Annak ellenére, hogy ténylegesen nem gyakorolnak hatást az adott cselekvéshelyzetre, mégis megteremtik a kontroll illúzióját (Comer 2010: 152-155). A kognitív magyarázat ezt azzal egészíti ki, hogy az obszesszív gondolatok eredetileg a szorongató benyomások semlegesítésére kerülnek kidolgozásra. Abban az esetben ugyanakkor, ha ezeket preventív jelleggel kezdi használni az egyén, a cselekvéshelyzetek társas-pragmatikus logikájától eloldódnak, és szüntelenül megidézve könnyen kontrollálhatatlanná válnak (Comer 2010: 155-156).

A kényszerzavarok fenti magyarázataiból kirajzolódnak a terápiás tekintet számára feltáruló okok, melyek e tartalmukat tekintve változatos formájú viselkedési megakadások hátterében állnak. A kritikai elmélet számára ezeket kell a különböző hálózati konfigurációk vonatkozásában újraértelmezni. A kényszerbetegségek a szocializációs pálya torzulásával hozhatók összefüggésbe abban az értelemben, hogy olyan társas viszonyokra utalnak, ahol sem a szorongások forrásának feltárására és megszűntetésére, sem nyilvánossá tételére nincs mód. Ilyenkor az egyén kénytelen olyan privát rítusokat kialakítani, melyek a kontroll illúziójával kecsegtetve, ideiglenesen csökkentik a szorongást, ugyanakkor totálissá válva ellehetetlenítik a hétköznapi cselekvést. A rítusok privát jellege és a társas cselekvést ellehetetlenítő, totalizáló tendenciája szorosan összefügg egymással. A privát gondolat- és viselkedésmintázatok épp azáltal képesek megteremteni a kontroll illúzióját, hogy eloldódnak a cselekvéshelyzet - egyébként uralhatatlan - interszubjektív kereteitól, és létrehoznak egy olyan összefüggésrendszert, ami - független lévén a kezelhetetlen társas viszonyoktól - az egyén által átlátható és irányítható. Ebben az értelemben a kényszerbeteg a társas cselekvéshelyzeteket meghatározó interszubjektív normatív kereteket „privát normákra” cseréli.

A privát normák az interszubjektív normákhoz hasonlóan múködnek a tekintetben, hogy meghatározzák a cselekvés céljait és kereteit; abban azonban különböznek tőlük, hogy nem teszik lehetővé a másik viszszajelzéséhez való igazodást, ami a közös valóság fenntartásának, megújításának és stabilizálásának központi mechanizmusa. Ennek hiányában csakis a szüntelen ismétlés képes fenntartani a privát normákat. ${ }^{6} \mathrm{~A}$ repetitiv jellegből egyrészt az következik, hogy a privát normák rendkívül merevek, hisz csupán ismétlésükre van mód, megújításukra nincs. Másrészt ugyanebből a sajátosságból fakad a privát normák kényszeres jellege is: társak

6 Ezen a ponton érdemes Wittgenstein privát nyelv-argumentumát felidézni. Abból az következik, hogy ha a másikhoz való igazodás nélkül próbáljuk leírni a szabálykövetés praxisát, úgy óhatatlanul paradoxonhoz jutunk. Bizonyos értelemben e paradoxon fejeződik ki a kényszerbetegségekben. Az igazodás funkcióját annyiban képes átvenni a szüntelen ismétlés, hogy egy adott mintázatot fenn tud tartani, annyiban viszont már nem, hogy azt potenciálisan meg is tudja újítani a környezeti igényekhez igazítva. 
hiányában az egyén egyedül kénytelen fenntartásukról gondoskodni, amit csak a folyamatos gyakorlás tesz lehetővé. E két tényező felelős a kényszerek interszubjektív valóságtól elidegenedett, ugyanakkor ellenállhatatlan jellegéért. A feszültségekkel terhelt, egyúttal kontrollálhatatlan élethelyzet állandósulásának eredményeként a privát normák szüntelen ismétlése fokozatosan háttérbe szorítja a társas normákat, és kiszakít az interszubjektív valóságból.

A kényszerbetegségek ilyenformán azokban a társas normákkal szemben is érvényesített privát késztetésekben nyilvánulnak meg, melyek eredetileg az elviselhetetlen, ugyanakkor felfüggeszthetetlen társas viszonyokat megalapozó normák alternativájaként jöttek létre, ám végül repetitív és merev jellegükből fakadóan maguk válnak kontrollálhatatlan teherré. A privát normák abban az értelemben kínálnak kiutat az egyén szükségleteivel összeegyeztethetetlen relációkból, hogy érzelmileg ellensúlyozzák vagy szimbolikusan felülírják azokat. Ugyanakkor a feszültség ily módon történő csökkentének az az ára, hogy - a privát norma paradox mivolta okán - egy kényszeres, és végső soron magát a hétköznapi interszubjektív valóságon alapuló életet ellehetetlenítő viselkedésmintához vezet.

Mindezek fényében belátható, hogy azok a hálózatok járulnak hozzá a kényszerbetegségek fenntartásához, melyek egyfelől az egyén viselkedését folyton megakasztó normatív kereteket hoznak létre, másfelől nem lehetséges kilépni belőlük. Ebben az esetben az adott hálózatét felülíró privát szabályok kialakításával nyílik lehetőség a szimbolikus menekülésre. A késő modernitás különböző típusú társadalmi hálózatai esetében e feltételek más-más módon teljesülhetnek. Mindegyik esetében végig lehet gondolni, hogy pontosan miként válhatnak egyszerre elviselhetetlenné és megváltoztathatatlanná az egyén számára, valamint azt is, hogy milyen privát rítus teszi szimbolikusan lehetővé a menekülést.

\section{2. ábra: A társadalmi hálózatok kényszerbetegségeket valószínüsitő torzulásai}

\begin{tabular}{|l|l|l|l|}
\hline & preintencionális & intencionális & posztintencionális \\
\hline Bourdieu & kétkedő habitus & $\begin{array}{l}\text { leleplezett, reményvesztett } \\
\text { illúzió }\end{array}$ & mobilitást ellehetetlenítő mező \\
\hline Giddens & eltitkolt rutinok & elidegenítő kognitív reflexivitás & $\begin{array}{l}\text { kiegyensúlyozatlan reflexív } \\
\text { intézmény }\end{array}$ \\
\hline Habermas & dogmatikus életvilág & elidegenült kommunikáció & eldologiasító rendszer \\
\hline Honneth & $\begin{array}{l}\text { erőszak vagy emberi játszmák } \\
\text { által torzított szeretet }\end{array}$ & $\begin{array}{l}\text { teljesítmény méltánytalan } \\
\text { értékelése }\end{array}$ & látszólagos jogi elismerés \\
\hline Lash & totális információ & $\begin{array}{l}\text { nem társadalmasítható } \\
\text { esztétikai reflexivitás }\end{array}$ & $\begin{array}{l}\text { átláthatatlan technikai-tárgyi } \\
\text { környezet }\end{array}$ \\
\hline
\end{tabular}

A habitusok által szervezett hálózatokban a cselekvők begyakorolt stratégiák segítségével küzdenek materiális és szimbolikus előnyökért. E hálózatok akkor válnak elviselhetetlenné az egyén számára, ha az nem tud az adott játszmában önfeledten, egyúttal sikeresen részt venni. Vagyis, ha a korábban begyakorolt habitus nem ruházza fel magától értetődőséggel a célokat és stratégiákat, és nem bizonyul hatékonynak. Ilyenkor a cselekvő folyamatosan elbizonytalanodik döntéseiben és kételyek gyötrik tevékenysége értelmével kapcsolatban, ami végső soron megakadályozza magát a hétköznapi cselekvést. Amennyiben arra sincs lehetősége, hogy új játszmába vesse bele magát, úgy megterhelő helyzetben találja magát: egyrészt nem tud azonosulni a környezet által sugallt vágyakkal és viselkedésmintákkal, ugyanakkor nincs módja kilépni az általuk meghatározott keretek 
közül. Elhúzódó esetben erre az egyén a - számára játszhatatlan, ugyanakkor alternatíva nélküli - játszma normatív alapjainak privát szabályokra való cseréjével reagálhat. Példaként elképzelhető egy vállalkozó családban felnövő gyerek, akihez szülei kizárólag a gazdaságosság szempontjai szerint viszonyulnak, és akivel eszerinti interakciókat folytatnak. Ennek hatására a teljesítménykényszer elviselhetetlenné válik számára, amire a viselkedését egyre nagyobb mértékben irányító rögeszmés babonákkal reagál. Az ilyen válaszok segítségével az eredeti feszültség csökkenthető ugyan, ám azon az áron, hogy kényszeres viselkedésmintázat alakul ki.

Az illúziók szerepe a társadalmi játszmák hatalmi jellegének elfedése, és ezáltal történő legitimálása. Abban az esetben válnak az egyén számára diszfunkcionálissá, ha nem képesek összebékíteni a tényleges élethelyzetet az elvárásokkal, vagyis nem kínálnak elfogadható magyarázatot a hiányokra és kudarcokra. Amennyiben a fennálló viszonyokkal való elégedetlenséget semmi sem pacifikálja, úgy az tényleges tapasztalattá válik. Ilyenkor kulcskérdés, hogy lát-e az egyén lehetőséget helyzete megváltoztatására vagy sem. Ez utóbbi esetben az elégedetlenség kilátástalanságba fordul át, ez pedig könnyen a privát szabályok által meghatározott cselekvésformákba való meneküléshez vezethet. Példaként elképzelhető egy olyan nő, aki rádöbbenve arra, hogy férfi kollégáinál ugyanazon munka elvégzéséért kevesebb bért kap, ugyanakkor megtapasztalva, hogy ez a helyzet nem megváltoztatható, nemi különbségekkel kezdi magyarázni a hétköznapi élet összes jelenségét. Bár lokálisan az ilyen reakció hatására a belső feszültség csökken, ám potenciálisan egyúttal egy új, kontrollálhatatlan függőség alakul ki.

A mezők a társas cselekvések lehetőségterét meghatározó struktúrák. Miközben a birtokolt szimbolikus és materiális tőke mértékétől függően korlátozzák a megtehető dolgok körét, egyúttal kijelölik a felhalmozás kereteit is. Más szóval felvillantják a mobilitás horizontját. Az egyén számára a mezők akkor elviselhetetlenek, ha a különböző tőkék megszerzését ellehetetlenítik, és ebben az értelemben bezárják adott élethelyzetébe. A változás perspektívájának hiányát a fennálló struktúra tagadása, vagyis privát szimbolikus tőkék felhalmozása képes ellensúlyozni. Példaként elképzelhető egy az oktatás világában folyamatosan előítéletekkel szembesülő fiatal, aki a kudarcok hatására az iskolai érdemjegyek helyett matricagyűjtésre szenteli minden figyelmét. Az ehhez hasonló reakciók a tényleges cselekvés illúzióját hordozva, csökkentik a reményvesztettséget, ugyanakkor egy izolált valóságba zárják az egyént.

A rutinok által szervezett cselekvési hálózatok feladata az ontológiai biztonság megteremtése. Ez abban az esetben lehetetlenül el, ha a személyesen kialakított rutinokat a közösség - tényleges vagy anticipált elismerése megvonással sújtja. Ilyenkor a rutinokat kénytelen eltitkolni az egyén, és egyedül gyakorolni. A szigorúan privát módon alkalmazott rutinok - a szüntelen ismétlésre való ráutaltságuk okán - óhatatlanul kényszeressé válnak, háttérbe szorítva a társas normákat a viselkedés szervezésében. Példaként egy olyan fiatalt képzelhetünk el, akit, miután társai kinevettek vallásossága miatt, rítusait titokban gyakorolja, aminek eredményeként az imádkozás eloldódik a társadalmi cselekvéshelyzetektől, és egyfajta szüntelen, belső háttérzajjá válik. Az eredeti szokás titkosítása elkerülhetővé teszi a szégyent és ennyiben csökkenti a feszültséget, ugyanakkor egyúttal kontrollálhatatlanná is teszi a rítust, és ezáltal potenciálisan új nehézséget teremt.

A kognitív reflexivitás egy lehetőség arra, hogy a társadalmilag fenntartott illúziók vagy szemantikák követése helyett, az egyén autonóm módon, többféle szakértői tudás felől reflektálva értelmezze a valóságot. 
Ugyanakkor ennek az egyéni értelmezésnek is megvannak a maga kvázi-társadalmi szabályai: ezek nem mások, mint a szakértői tudások racionalitási kritériumai. A hozzájuk való igazodás abban az esetben lesz elviselhetetlen, ha adott hálózati konstellációban kizárólagossá válik és felszámolja a racionalitástól független - például érzelmi alapú - értelemképződést. Abban az esetben, ha nincs lehetőség a kognitív reflexió és az alapjául szolgáló racionalitás ideiglenes felfüggesztésére, saját magától idegenül el az egyén. Az ily módon fokozatosan növekvő feszültség elől kínálhat menekülési útvonalat a racionalitás normái helyett, egy saját dogmarendszert kialakítva, az irracionalitás privát szabályaihoz alkalmazkodni. Példaként egy olyan egyénre érdemes gondolni, akit kora gyermekkorától a racionalitás kizárólagosságára neveltek, ám minthogy ez érzelmi kihívások esetén nem kínál vigaszt, ezért irracionális, ezoterikus praktikákban keres megnyugvást. Az ilyen helyzetekben a reflexió feladása az érzelmi sivárságot csökkenti ugyan, ám azon az áron, hogy egy kényszeres gondolkodást állandósít, eltávolítva a racionalitás alapján szerveződő hálózatoktól.

A reflexív intézmények feladata, hogy szakértői tudásuk szempontjai szerint, de a cselekvők igényeihez alkalmazkodva biztosítsák egy térben és időben kiterjedt hálózat kereteit. Belátható, hogy a reflexív intézmények hatékonysága a konkrétság és az absztrakció egymásnak ellentmondó igényei közti egyensúlyozáson múlik: amennyiben az előbbi kerül túlsúlyba, úgy a szakértői jelleg csökken, amennyiben az utóbbi, úgy a rugalmasság. Ennek megfelelően az egyén szempontjából a reflexív intézmények akkor válnak diszfunkcionálissá, ha az egyensúly felborul. Ilyenkor az egyénre többletfeladatok hárulnak: előbbi esetben a szakértői tudás megszerzésének, utóbbi esetben az alkalmazkodásnak a terhe. Amennyiben a diszfunkcionálissá vált reflexív intézményeknek nincs alternatívájuk, úgy e terhek állandósulnak. Erre reagálva választhatják az egyének az intézményi interakciókban a közösnek ellentmondó privát szabályok követését. Példaként elképzelhető egy nevelési tanácsadóval kapcsolatban álló szülő, aki merev, dogmatikus tanácsokat kapva, a közös interakciókat kényszeresen hárítja, a legkülönfélébb indokokra hivatkozva. Az ehhez hasonló kísérletek ugyan csökkentik az intézményi interakció kudarcából fakadó tehetetlenség érzést, ugyanakkor a privát szabályok merev követése magában rejti a kényszerzavarok fenntartásának veszélyét.

Az életvilág a magától értetődő közös valóság terepeként a normalitás elemi szintjét jelöli ki. A természetesként adott jelentéshorizonton alapuló hálózatok az egyén számára abban az esetben válnak diszfunkcionálissá, ha a cselekvés megakadása esetén nem kínálnak lehetőséget az életvilág nyilvános interakcióban történő megváltoztatására. Ilyen dogmatikus életvilágnak tekinthető például egy névleg demokratikus, valójában diktatórikus politikai rendszer, melyben mindenki kényszeres színlelésre és képmutatásra van kárhozatva: ilyenkor a valóság közös értelmezésében csak látszólag osztozik társaival az egyén, miközben valójában ellehetetlenül a saját álláspont őszinte kifejezése, valamint a magától értetődő, közös cselekvési célok és értékek szerinti cselekvés. A cselekvést megakasztó, ugyanakkor merev életvilág helyett az egyén a valóság privát értelmezését dolgozza ki. A cselekvéseit ehhez igazítva, lehetősége nyílik arra, hogy virtuálisan elmeneküljön vagy szimbolikusan elhatárolódjon a dogmatikus életvilágtól. E privát szabályok által meghatározott valóságot belakva - más szóval annak jelentéseit kényszeresen ismételve - megteremtheti ugyan önmaga számára a függetlenség illúzióját, ám ennek ára a privát késztetésektől való új függőségi viszony lesz. 
A kommunikatív cselekvés központi funkciója a társas cselekvések kölcsönös megértés révén történő koordinációja. Az ilyen hálózatok akkor válnak az egyén számára elviselhetetlenné, ha nem teszik lehetővé konszenzuális közös valóság kialakítását. Ha az ilyen értelemben torzított kommunikációnak, akár strukturális, akár normatív okokból nincs alternatívája, hatalmi viszonyok jelennek meg az interakciók elemi szintjén. Ilyen kommunikációs viszonynak tekinthetők a hosszú távú együttmúködésre kényszerített, ugyanakkor közös valóságot kialakítani képtelen tanár-diák, gyerek-szülő, élettársi vagy kortárs relációk, melyekben kölcsönös megértésre törekvő kommunikáció helyett csupán stratégiai „emberi játszmák” lehetségesek. Ezek hatását ellensúlyozandó, az egyén a kommunikatív cselekvéshez olyan - akár pusztán önmaga, akár mások számára is hozzáférhető - jeleket kapcsolhat, melyek megtörik, vagy - az elfogadhatatlan viszonyt idézőjelbe tevő - többletjelentéssel ruházzák fel a beszédaktusok egymásra reagáló szekvenciáját. Példaként elképzelhető a kifejezések privát szabályok szerinti használata, a kommunikatív cselekvésből - tényleges vagy virtuális partner felé - történő kikacsintás, vagy a dialógus logikájának egyéb beszéd- vagy nem-nyelvi gesztus révén történő megakasztása. Azáltal, hogy ezek a kommunikáció elemi normáit szétfeszítő privát szabályok rutinná válnak, az elfogadhatatlan kommunikatív viszonyból fakadó feszültség csökkenthető. Igaz, ezzel az egyén kommunikatív kompetenciáját, vagyis a többiekhez való kapcsolódás elemi képességét veszélyezteti.

A társadalmi alrendszerek az instrumentális cselekvések hatékony megvalósítását teszik lehetővé. Az egyén számára akkor válnak diszfunkcionálissá, ha a célok hatékony megvalósítását ellehetetlenítik. Ilyenkor a médiumok által koordinált cselekvéshelyzetek az egyén számára kilátástalanná válnak: a cselekvő puszta dologgá lesz bennük, aminek szempontjai teljesen indifferensek. Minél kevésbé van lehetőség kilépni az ilyen alrendszerek hálózataiból, annál nyomasztóbbá válnak az egyén számára. Példaként elképzelhető egyaránt egy jogszabály, ami ahelyett, hogy segítene tisztázni egy vitás kérdést, valójában csak az esetlegességet növeli, vagy egy monopol féllel kötött üzleti tranzakció, ami ahelyett, hogy méltányos cserét tenne lehetővé, valójában szabad utat enged a visszaélésnek. Az ehhez hasonló helyzetek visszásságát ellensúlyozandó, az egyén az alrendszerek múködését megakaszthatja: képzeletben vagy ténylegesen átértelmezve az alapjukul szolgáló médiumokat, a magától értetődőségükből fakadó automatikus működésüket kontingenssé teheti. Amennyiben ezek az alrendszereket ellehetetlenítő privát szabályok állandósulnak, az egyéni instrumentális célok megvalósíthatatlanságából fakadó frusztráció enyhül. Ugyanakkor ennek hátulütője, hogy újfajta függőségek alakulnak ki, melyek ráadásul fokozatosan izolálják is az egyént.

A szeretet mint elismerési forma az önbizalmat alapozza meg. A szeretet által szervezett intim hálózatok akkor válnak elviselhetetlenné az egyén számára, ha csökkentik az önbizalmat, ami egyrészt nyílt erőszak, másrészt rejtett emberi játszmák hatására következhet be. Amennyiben nincs lehetőség a kapcsolat megszüntetésére, úgy az egyén privát szabályok szerint szerveződő kényszeres rítusok vagy függőségek révén próbálhatja az autonómia illúzióját megteremteni. Példaként elképzelhetünk egy fiatal lányt, aki szülei hiába vágyott elismerését az iskolai sikerek kényszeres hajszolásával próbálja ellensúlyozni. Ezzel csökkenti ugyan az elismeréshiányból fakadó rossz érzését, ám kiszolgáltatottá válik egy másfajta függésnek.

Az egyéni teljesítmény társak általi elismerése az önbecsülés záloga. A teljesítményelven alapuló hálózatok abban az esetben válnak diszfunkcionálissá, ha a hasznosság helyett a haszontalanság érzését erősítik meg. 
Ez egyaránt bekövetkezhet az értékelés meritokratikus kereteinek hiánya vagy az esélyek egyenlőtlensége okán. Amennyiben nem áll módjában az egyénnek elhagyni az ilyen hálózatokat, úgy a teljesítmény kollektív mércéit privát szabályokkal válthatja fel. Példaként elképzelhetünk egy szalagmunkást, akinek teljesítményét személyes antipátia miatt főnöke igazságtalanul itéli meg, aminek hatására a hatékonyabb termelés szempontjai helyett privát rítusok szerint kezdi munkáját végezni. Az ehhez hasonló megoldások révén az elismeréshiányból fakadó sérelem ellensúlyozható, ugyanakkor egyre kevésbé teszi összeegyeztethetővé a termelékenység szempontjait és a kényszeres szokásokat.

A jogi elismerés a saját morális kompetencia kialakulásához nélkülözhetetlen. A jog által integrált hálózatok akkor válnak diszfunkcionálissá az egyén számára, ha a méltóság - jog előtti egyenlőségből fakadó tapasztalata helyett az alávetettség - önkényből fakadó - tapasztalatát eredményezik. Amennyiben e sérelmek orvoslására nincs mód, úgy az egyén a társadalmi normákat érvénytelennek tekintheti és helyettük privát szabályokhoz kezd igazodni. Példaként elképzelhető egy fokozott hatósági zaklatásnak kitett vállalkozó, aki kiszámíthatatlan helyzetére tisztasági rítusok kifejlesztésével reagál. Ez lokálisan ugyan enyhíti a méltánytalan eljárásból fakadó kínokat, ám egyúttal olyan függőséget eredményez, ami megnehezíti a hétköznapi életvitelt.

Az információ a valóság értelmezésének olyan formájaként értelmezhető, ami lehetővé teszi azt, hogy valós időben igazodjanak egymáshoz a cselekvők. Ez ugyanakkor sajátos nehézségekkel jár: a potenciálisan permanens alkalmazkodás felszámolja az egyedüllét terét. Ennek hiányában mind az otthonosságot biztosító személyes rutinok, mind pedig az önreflexió ellehetetlenül. Abban az esetben, ha az információ révén történő cselekvéskoordinációnak nincs alternatívája, úgy az elidegenítően hat. Erre az információáramlás normativ kereteinek felfüggesztésével válaszolhat a cselekvő, vagyis az információt átértelmező kényszercselekvés formáját öltő személyes rutinok követésével. Példaként elképzelhető egy tőzsdeügynök, aki a rá nehezedő fokozott vállalati nyomásra a sikert szavatolni hivatott számmisztika kifejlesztésével reagál. Ez képes ugyan enyhíteni a világban való otthonosság és a személyes identitás konstrukciójához szükséges tér hiányát, ugyanakkor könynyen kontrollálhatatlanná válhat.

Az esztétikai reflexivitás a társadalmi kategóriáktól való függetlenedés lehetőségét rejti magában. A kreativ, autonóm értelemképződés ugyanakkor rá van utalva a társas interakciókra abban az értelemben, hogy eredményei csakis közös valóságként stabilizálhatók. Elviselhetetlenné éppen ezért az esztétikai reflexivitáson alapuló hálózatok abban az esetben válnak, ha nem tesznek lehetővé egy közös társadalmi valósághoz való kapcsolódást. Ilyenkor az értetlenség terhe szakad az egyénre, hosszútávon izolálva a társaktól. Azokban a hálózatokban, ahol az esztétikai reflexivitásnak nincs alternativája, a visszajelzés - kommunikációs nehézségekből fakadó - hiányára kényszercselekvésbe vagy függőségbe meneküléssel reagálhat az egyén. Példaként egy olyan múvészre gondolhatunk, aki meg nem értettségére a megerősítést „mágikus” jelek kiolvasásából nyeri. Az ilyen kényszercselekvések egyrészt csökkentik az újabb kudarctól való félelmet, azonban kényszeressé válva akadályozzák a hétköznapi életet.

A technikai-épített környezet az instrumentális cselekvés minden korábbinál hatékonyabb eszközeihez való hozzáférést tesz lehetővé. Ez ugyanakkor korántsem problémamentes lehetőség: az eszközök használatához szükséges tudás strukturálása, vagyis az eszközök kompetens használata komoly nehézségeket rejt magá- 
ban. A technikai-épített környezet hálózatai ebből fakadóan oly módon válhatnak diszfunkcionálissá az egyén számára, ha átláthatatlanná és egyúttal kezelhetetlenné válnak. Ilyenkor a végtelen lehetőségek ígérete és a tényleges célelérés korlátai frusztráló kontrasztot képeznek. Amennyiben egyéb hálózatokban nincs lehetőség a technikai-tárgyi környezet múködtetéséhez szükséges kompetencia pótlására és a frusztráció állandósul, úgy arra a privát használati szabályok kialakításával reagálhat az egyén. Példaként egy olyan irodai munkásra gondolhatunk, akinek idegen, ugyanakkor munkája során nélkülözhetetlen terep a számítógép, amire oly módon reagál, hogy kényszeresen igyekszik tisztán tartani gépét, ettől várva hatékony működését. Ezáltal ugyan csökkenti a feszültséget, ugyanakkor függőséget alakít ki, ami hosszútávon munkáját is ellehetetleníti.

A fentiekben a társakhoz való kapcsolódás ideáltipikus hálózati konfigurációinak szintjén külön-külön rekonstruáltam a kényszerbetegség kialakulásának és fennmaradásának társadalmi feltételeit. Önmagukban tekinteni ezekre a leírásokra megtévesztő lehet, minthogy e különböző hálózati típusok együttesen rajzolják ki az egyének kapcsolathálózatának lehetőségterét. Így előfordulhat, hogy bár egyik vagy másik hálózati típus szintjén torzulásokat találunk, azokat az egyéb hálózati típusok ellensúlyozni tudják. Ennek megfelelően, a kényszerbetegséget valószínűsítő élethelyzetek azonosításához párhuzamosan az összes hálózati szintet figyelembe kell venni. Csakis abban az esetben beszélhetünk kényszerbetegséget valószínúsítő társadalmi közegről, ha a fentiekben bemutatott torzult hálózati típusok dominálják az egyén kapcsolathálózatát. Abban az esetben ugyanakkor ez indokolatlan, ha annak ellenére, hogy torzult hálózati típusok is előfordulnak, mellettük jelentős az olyan hálózatoknak az aránya, ami ezek alternatíváját kínálja. Ilyenformán a torzult és nem torzult hálózatok aránya a döntő kérdés. Ez teszi lehetővé, hogy egy folytonos skálán értelmezzük a kényszerbetegség kialakulásának esélyét a különböző kapcsolathálózati konstellációk vonatkozásában. A nem torzult hálózatok mellett kiemelt jelentősége van azoknak a hálózatoknak is, melyek nem egyszerúen alternatíváját kínálják a problematikus hálózatoknak, hanem annak a lehetőségét rejtik magukban, hogy csökkentsék a kialakult pszichopatológiát. Az ilyen értelemben vett kvázi-terápiás hálózatokra szolgál példaként a kognitív terápia elemzése.

\section{A KOGNITÍV TERÁPIÁK HÁLÓZATI MODELLJEI}

Ahogy a pszichopatológiák azokat a határállapotokat fejezik ki, melyekben az átélt szenvedés megszüntetésére képtelenné válik az egyén, a pszichoterápiák azokra az ideáltipikus módszerekre utalnak, melyek segíteni hivatottak felszámolásukat. A különböző terápiás helyzetekre olyan interakcióként tekinthetünk, melyeket a páciens problémája és a terapeuta által alkalmazott technikák közösen határoznak meg. Ebben az értelemben a terápia egy sajátos hálózati konfigurációnak tekinthető, melyben a hálózat alkotóelemeit és a kötések logikáját egyaránt a páciens problémájának kezelési szempontjai határozzák meg. A terápiás hálózatok azzal a szándékkal jönnek létre, hogy a pszichopatológiákat fenntartó hálózatok destabilizálódjanak és átadják helyüket egyéb formációknak. Ennek megfelelően a pszichoterápiás gyakorlatok oly módon kínálnak elméleti szempontokat a kritikai elmélet számára, hogy feltárják azokat a hálózati dinamikákat, melyek képesek a patologikussá vált szenvedés pályájáról kimozdítani a cselekvőt. Ahhoz, hogy a kritikai elmélet számára hasznosíthatóak legyenek, a terápiás helyzetekre olyan határállapotként kell tekinteni, melyek ideáltipikus formában feltárják a különböző pszichopatológiákból kivezető utakat. Amennyiben dinamikus hálózatokként értelmezzük újra őket, azok a hétköznapi cselekvéshelyzetek is azonosíthatóvá válnak, melyek hatásukban a terápiás helyzetekkel állíthatók párhuzamba. 
A kognitív terápia kifejlesztése Aaron Beck nevéhez fúződik (Beck 1975), aki a kognitív tanuláselméletekből kiindulva amellett érvel, hogy a pszichológiai problémák kialakulásának megértésében jelentős szerepet töltenek be a rögzült gondolkodási sémák. Minthogy ezek keretezik a valóság értelmezését, így torzulásuk a valóság beszúkült percepciójához vezet. Ebből a szempontból kitüntetett jelentősége van azoknak a tanulási folyamatoknak, melyekben az alapvető hitek és sémák - ahogy Beck fogalmaz, „automatikus gondolatok” formálódnak: ezek szintjén ragadható meg mind a pszichopatológiák forrása, mind pedig a terápia lehetősége. A valóság értelmezését keretező maladaptív sémák elsajátításáért olyan kora gyerekkori tapasztalatok tehetők felelőssé, mint a biztonság és gondoskodás kiszámíthatatlansága, az önállóság és felelősségvállalás élményének hiánya, az egyén jogainak tiszteletben tartásához vagy a kooperációhoz kapcsolódó kudarcok, esetleg a társak visszajelzéseinek túlértékelése. Miközben e tapasztalatok meghatározó szerepet töltenek be a magunkhoz és másokhoz való viszony kialakulásában, az egyén alapértelmezésben mégis ritkán reflektál rájuk. Ebből fakadóan a valóság beszúkült értelmezését eredményező rejtett előfeltevésként vannak jelen a cselekvéshelyzetekben.

A gondolkodási torzulások számos formája közül a leggyakoribbak a kudarcoknak túlzott jelentőséget tulajdonító „túldramatizálás” vagy túláltalánosítás, a kizárólag negatív következményű események szelektív percepciója, a túlzottan kritikus véleménytulajdonítás és a kizárólag pesszimista várakozási horizont. Ezen - a valóságot szisztematikusan negatív keretbe ágyazó - attribúciós folyamatok eredményeként egy kiszámíthatatlan, fenyegető világgal találja szemben magát az egyén, mely élmény állandósulva a pszichopatológiák különböző formáihoz vezethet. A kognitív terápia során a gondolkodás torzulásainak e rejtett, automatikus pályáira történik reflexió. A terapeuta a páciens valóságértelmezését elemzi, és felhívja a figyelmet azokra a pontokra, ahol a maladaptív automatikus gondolatok csapdájába esik. Ez egyaránt magába foglalja a kártékony sémák problematikus cselekvéshelyzetek elemzése révén történő azonosítását, a sémák interpretációs és viselkedési következményeinek számba vételét és a hozzájuk kapcsolódó érzelmekre történő reflexiót. Tekintve, hogy a gondolkodás torzulásai egy tanulási folyamat eredményeként alakulnak ki, így a kognitiv terápia is egy olyan közös tanulásként írható le, melynek célja a maladaptiv sémák újraértelmezése, módosítása és átstrukturálása. E korrekciós tanulási folyamat a páciens felfokozott önmonitorozásán alapul: a terapeuta segítségével begyakorolja, hogyan ismerheti fel a maladaptív sémákat, így azok megszúnnek automatizmusként múködni. A reflexió segítségével múködési módjuk feltárható, és egyúttal átalakítható: alternatív sémákkal helyettesíthetők, a belőlük fakadó valóságértelmezések átdolgozhatóvá válnak, az érzelmi és viselkedésbeli következmények pedig végső soron megváltoztathatók lesznek (Sharf 2012: 373-389).

A kognitív terápia különböző változataiban közös, hogy a reflexió révén kívánják a valóságértelmezés megakadást okozó rejtett előfeltételeit megváltoztatni. Hálózatelméleti szempontból ez azt jelenti, hogy a terápiás helyzetben olyan reflexív hálózatot teremtenek, aminek perspektívájából a jelentéstulajdonítás természetesként adott aspektusai hozzáférhetővé és formálhatóvá válnak. A valóság értelmezésének folyamata hálózatelméleti keretek között az intencionális kötések által összekapcsolt hálózatok szintjén értelmezhető. Ez azt jelenti, hogy a valóságértelmezés egyaránt torzulhat az illúziók, a kognitív reflexivitás, a kommunikatív cselekvés, a szolidaritás és az esztétikai reflexivitás szintjén. A valóságértelmezés e különböző hálózati logikák szerinti torzulásainak kezelésére az alternativ logikák kínálnak lehetőséget: a hozzájuk igazodó jelentéstulajdonítás perspektívájából lehet reflexív viszonyt kialakítani a beszúkült sémákkal, és az ő kereteik között lehet átdolgozni azokat. 
Az alternatív hálózatszerveződési logikák egyúttal alternatív integrációs logikához igazodó cselekvési szférákat is kijelölnek, és ebben az értelemben a valóság értelmezésének alternatív tereire utalnak. A különböző integrációs logikákhoz igazodó cselekvők interakcióiban épp azáltal nyilik lehetőség a valóság magától értetődő értelmezésére történő reflexióra, hogy az egyén a sajátjától eltérő integrációs logikákhoz igazodó cselekvéshelyzetekben formálódó jelentéshorizonttal szembesül. A valóság eltérő keretek között történő interpretációjával való találkozás a - schützi értelemben vett (Schütz-Luckmann 1974) - „természetes beállítódás” magától értetődőségét függeszti fel. Olyan „problémaként” jelenik meg a cselekvő értelmezési horizontján, ami „reflektiv beállítódást” implikál, vagyis a korábban megkérdőjelezetlen jelentések átértékelésére késztet. Ilyenformán a különböző intencionális logikák szerint szerveződő hálózatok kapcsolódásaiban a kognitív terápiához hasonló folyamatok játszódnak le, amennyiben az „automatikus gondolatok” megkérdőjeleződnek.

A kognitiv terápiák a valóság értelmezésére tanulási és fejlődési kérdésként tekintenek. Ebből a szempontból a valóságértelmezés sémáit is differenciálatlanul kezelik, elmulasztva a maladaptív automatikus gondolatok kritikáját lehetővé tevő reflexív perspektívák hálózati logikák terében történő megragadásának esélyét. A tekintetben, hogy pontosan miként képzelhetők el az illúzió, a kognitív reflexivitás, a kommunikatív cselekvés, a szolidaritás és az esztétikai reflexivitás torzulásai, a kényszerbetegségek újratermelődését valószínűsítő táblázat nyújt tájékoztatást. A lehetséges kezelési módokat illetően pedig a komplementer hálózati konfigurációk modelljei. Az alábbiakban ezeket tekintjük át röviden.

A szimbolikus és materiális mezőküzdelmek kereteit és céljait legitimáló illúziók vonatkozásában akkor beszélhetünk maladaptív gondolkodási sémákról, ha azok nem képesek a fennálló kereteket legitimálni vagy éppen reményvesztettséget tükröznek. Amennyiben az ilyen értelemben torzult hálózatokhoz hosszútávon kénytelen kapcsolódni az egyén, úgy gondolkodási sémái ezekhez kezdenek igazodni, olyan beszúkült várakozási horizontot hozva létre, ami kihat a további hálózati konfigurációkra is. A torzult illúziók kezelésére olyan cselekvői, intézményi vagy esztétikai reflexivitáson alapuló, illetve kommunikativ cselekvési vagy szolidaritási hálózathoz való kapcsolódás révén nyilik lehetőség, amelyek segítségével a cselekvő számára alapértelmezésben magától értetődő illúziók reflexió tárgyává tehetők. A szakértői tudás, a kommunikációban születő konszenzus, az autonóm értelemképződés vagy a megbecsülés egyaránt olyan tapasztalatnak tekinthetők, melyek perspektivájából megkérdőjelezhetők az illúzióból következő sémák. Az egyéni és intézmények által közvetített szakértői tudások a különböző álláspontok közti mérlegelésen alapulnak, ebből fakadóan a relativizálásból fakadó reflexivitást szegezik szembe az illúziók automatikus működésével. A kommunikatív cselekvésben kifejeződő kölcsönös megértés a különböző cselekvőhorizontok közelítésén alapul, ilyenformán a sémák magától értetődősége helyett az interaktív reflexió lehetőségét rejti magában. Az egyéni kvalitások és teljesítmények társak általi elismerése az önbecsülést erősíti, és ezáltal a materiális és szimbolikus tőkékért folyó küzdelem szabályaihoz szabadabb viszonyulást tesz lehetővé. Az esztétikai reflexivitás az autonómia radikális formájára utal, ily módon a sémáktól való távolságtartásra motivál. A fenti hálózatokban az illúzió logikája által szervezettől eltérő kognitív tanulási folyamatok zajlanak le, melyek mentesek az illúzió torzulásaitól. Ebben az értelemben e hálózatok potenciálisan hasonló szerepet töltenek be, mint a kognitív típusú terápiák: teret kínálnak a beszúkült gondolkodási sémákra történő reflexióra és megváltoztatására. 
A kognitiv reflexivitás által szervezett hálózatok vonatkozásában akkor beszélhetünk maladaptív gondolkodási sémákról, ha a reflexió elidegenítő hatású. Ezekben a hálózatokban a gondolkodási sémákra rányomják bélyegüket magát a gondolkodást kísérő negatív élmények, aminek hatására a reflexivitás kötött pályán kezd mozogni, és végső soron ellehetetlenül. A reflexivitás torzulásainak kezelésére olyan kommunikatív cselekvésen, esztétikai reflexivitáson, illúziókon vagy szolidaritáson alapuló hálózatokban nyílik lehetőség, amelyek segítségével a gondolkodás automatizmusai reflexió tárgyává tehetők. Az illúziók a különböző társadalmi gyakorlatokkal való azonosulás révén járulhatnak hozzá a megakadt reflexív folyamatok beindításához: a reflexió folyamatát a társadalmi játszmák dinamikájához hozzákötve, egyúttal a gondolkodás kereteit is mozgásba lendítik. A kommunikatív cselekvés a reflexió folyamatát a szubjektivitás teréből az interszubjektivitás terébe emeli át, és ebben az értelemben lehetőséget teremt annak megszokott mederből történő kizökkentésére. Az egyéni életformák és teljesítmények elismerése, az önbecsülés alakításán keresztül nem csupán az autonómia mértékét befolyásolva, de egyúttal a másokhoz való viszonyra is kihatva keretezheti újra a reflexiót. Az esztétikai reflexivitás a külsődleges szempontoktól való függetlenség tapasztalatát idézi meg, és ilyenformán megnyitja az utat önmagunk és a világ átértelmezése előtt.

A kommunikatív cselekvés kapcsán akkor beszélhetünk maladaptív gondolkodási sémákról, ha az interakciók elidegenültek. Az ilyen hálózatokban a valóságértelmezés sémái a kommunikáció torzulásaihoz igazodva maguk is beszúkülnek. A kommunikáció torzulásainak kezelésére olyan cselekvői, intézményi vagy esztétikai reflexivitáson, illúziókon vagy szolidaritáson alapuló hálózatokban nyilik lehetőség, amelyek segítségével a kommunikáció alapértelmezésben magától értetődő keretei reflexió tárgyává tehetők. Az illúziók a valóság értelmezésének magától értetődő kereteit társadalmi játszmákhoz kötve az interszubjektív viszonyokat is saját mércéik szerint ítélik meg, mely perspektívából a kommunikáció torzulásai is új megvilágításba kerülnek. A szakértői tudás által szervezett hálózatok a kommunikáció racionális modelljére utalnak, amennyiben a szakértői tudások megítélése és mérlegelése egyaránt a jobbik érv kiválasztásán alapul. Ennek megfelelően e hálózatok az uralommentes, érvelő vita modelljét implikálják, szemben a szisztematikusan torzított beszélgetéssel. Az egyéni létforma elismerése, megerősítve az önbecsülést, egyúttal az interakciókban is egy magabiztos, autonóm fellépést valószínúsít. Az esztétikai reflexivitás a társaktól való függetlenség terepeként lehetővé teszi a torzult interszubjektív viszonyról való lekapcsolódást, és ezáltal előkészíti az interakció beszúkült kereteire történő reflexiót is. Mindezekben a hálózatokban a kommunikatív cselekvéstől eltérő tanulási folyamatok keretében lehetőség nyílik a torzult sémák átdolgozására.

A megbecsülésen alapuló hálózatokban akkor alakulnak ki maladaptív gondolkodási sémák, ha a túlfeszített teljesítmény elismerési feltételei méltánytalanok. Ezekben a hálózatokban a cselekvők önbecsülése és a megbecsülés keretei egyaránt beszúkült vagy paradox pályára terelődnek, aláásva a világhoz való viszony minden aspektusát. A megbecsülés torzulásainak kezelésére olyan cselekvői, intézményi vagy esztétikai reflexivitáson, illúziókon vagy kommunikatív cselekvésen alapuló hálózatokban nyílik lehetőség, amelyek segítségével az elismerés alapértelmezésben nem hozzáférhető keretei reflexió tárgyává tehetők. Az egyes illúziók a megbecsülés különböző kereteit jelölik ki, és ebben az értelemben az elismerés olyan összetett játékterére utalnak, ahol az eltérő dimenziók kompenzatórikus szerepet tölthetnek be. A szakértői tudások alapján szerveződő hálózatok a megbecsülés általános, intézményesített kereteit is kijelölik, és ennyiben a lokális elismerési viszo- 
nyokra történő reflexiót és kritikát is lehetővé teszik. Az uralommentes viták az elismerés különböző formáinak egyaránt kitüntetett terepei: minthogy egyszerre kínálnak lehetőséget a másik méltóságának, egyediségének és teljesítményének elismerésére, így a megbecsülés kereteinek megújulása hozzájuk is köthető. Az esztétikai reflexió logikája szerint szerveződő hálózatok a másik elismerésétől való függetlenedés lehetőségét rejtik magukban, ennyiben pedig a megbecsülés torzulásaira történő reflexióét és az azoktól való függetlenedését is.

Az esztétikai reflexivitás maladaptív mintázatairól abban az esetben beszélhetünk, ha a közös valóságtól való teljes leszakadással jár, vagyis az annak során született jelentések kommunikálhatatlanok. Az ilyen hálózatokban az autonóm értelemképződés olyan sémái alakulnak ki, melyek az egyén önmagához és másokhoz való viszonyát egyaránt torzítják. Az esztétikai reflexivitás torzulásainak korrekciójára olyan cselekvői és intézményi reflexivitáson, illúziókon, elismerési viszonyokon vagy kommunikatív cselekvésen alapuló hálózatokban nyílik lehetőség, amelyek segítségével az esztétikai reflexivitás alapértelmezésben nem hozzáférhető folyamatai reflexió tárgyává tehetők. Az illúziók abban az értelemben járulhatnak hozzá az esztétikai reflexivitás kereteinek átdolgozására, hogy adott társadalmi játszma keretei között a szabályok kreatív újradefiniálására ösztönöznek, és ezáltal a tőlük való függetlenedés begyakorlásának terepéül szolgálnak. Az egyidejűleg többféle szakértői tudás által szervezett hálózatokban egyszerre nyílik lehetőség a reflexivitásnak, valamint a reflexió eredményeinek a közös valósághoz kapcsolására, így az esztétikai reflexivitás korlátaihoz való hozzáférésre is. Az uralommentes vita, hasonlóképpen az esztétikai reflexióhoz, az életvilágtól való függetlenséget túzi ki célul, minthogy azonban ezt egy interakció keretében teszi, így - a közös gondolkodásból fakadó transzparencia igény okán - magában foglalja a lehetőségét a reflexió folyamatára történő reflexiónak is. A megbecsülés által szervezett hálózatok az esztétikai reflexivitáshoz nélkülözhetetlen önbecsülés születési helyei is egyúttal, ezáltal képesek a torzult gyakorlatok átalakítására.

A kényszerbetegségek, valamint a kognitív terápiák hálózati elemzéséből következő összefüggéseket az alábbi táblázat foglalja össze. 


\section{3. ábra. A kognitiv terápia hálózati modelljei (a kényszerbetegségek vonatkozásában)}

\begin{tabular}{|l|l|}
\hline $\begin{array}{l}\text { intencionális hálózati torzulások } \\
\text { (kényszerbetegségek } \\
\text { vonatkozásában) }\end{array}$ & terápiás lehetőség (a kognitív terápia vonatkozásában) \\
\hline $\begin{array}{l}\text { leleplezett, reményvesztett } \\
\text { illúzió }\end{array}$ & $\begin{array}{l}\text { az illúzió magától értetődőségét felhasító szakértői tudásból fakadó reflexivitás } \\
\text { vagy kommunikatív cselekvésből fakadó interszubjektív reflexió, a mezőharc } \\
\text { logikáját megtörő szolidaritás, az illúziótól való függetlenségre törekvő esztétikai } \\
\text { reflexivitás }\end{array}$ \\
\hline elidegenítő kognitív reflexivitás & $\begin{array}{l}\text { a gondolkodást társadalmi gyakorlatokhoz kötő illúzió, a szubjektivitás teréből az } \\
\text { interszubjektivitás terébe átemelő kommunikatív cselekvés, az önálló reflexió- } \\
\text { hoz szükséges önbecsülést megerősítő szolidaritás, a gondolkodást újraalapozó } \\
\text { esztétikai reflexivitás }\end{array}$ \\
\hline elidegenült kommunikáció & $\begin{array}{l}\text { a kommunikációt társadalmi tétekkel relevánssá tevő illúzió, a szakértői tudásban } \\
\text { rejlő racionalitáspotenciált a kommunikatív folyamatokba becsatornázó kognitiv } \\
\text { reflexivitás, az interakcióhoz szükséges autonómiát megerősitő szolidaritás, az } \\
\text { interakciók beszúkült kereteit dekonstruáló esztétikai reflexivitás }\end{array}$ \\
\hline teljesítmény méltánytalan & $\begin{array}{l}\text { a teljesítmény alternatív dimenzióit feltáró illúzió, a teljesítmény méltányos } \\
\text { kereteit kijelölő szakértői tudás, a megbecsülés kereteit interaktívan megújító } \\
\text { kommunikatív cselekvés, a megbecsüléstől való függetlenedést lehetővé tevő } \\
\text { esztétikai reflexivitás }\end{array}$ \\
\hline $\begin{array}{l}\text { nem társadalmasítható } \\
\text { esztétikai reflexivitás }\end{array}$ & $\begin{array}{l}\text { lódó szakértői tudás, az életvilágról való interszubjektív lekapcsolódás lehetősé- } \\
\text { gét magában rejtő kommunikatív cselekvés, az autonóm értelmezések közléséhez } \\
\text { szükséges önbecsülést megteremtő szolidaritás }\end{array}$ \\
\hline
\end{tabular}

A kognitív terápia múködését imitáló hálózati konfigurációk a pszichopatológiákat valószínúsítő hálózatokhoz kapcsolódva azok hatását potenciálisan semlegesítik. A kényszerbetegségek esetében ez azt jelenti, hogy az elviselhetetlen, ugyanakkor megváltoztathatatlan társas normák előli menekülést biztosító, kényszeres ismétlésen alapuló privát normáktól való függőséget - a kognitív terápiák mintájára - a komplementer intencionális hálózatok képesek megtörni, amennyiben ezek perspektívájából lehetőség nyílik a torzult intencionális hálózatokban kialakult maladaptív gondolkodási sémákra történő reflexióra és korrekcióra. Ahogy a pszichopatológiákat valószínúsítő hálózati konfigurációk esetében sem egy-egy torzító hálózat jelenlétét vagy hiányát, hanem az összes hálózaton belüli arányukat tekintettük, úgy a kvázi-terápiás szerepet betöltő hálózatok esetében is abból indulhatunk ki, hogy azok aránya jelöli ki a patológiák ellensúlyozásának esélyét. Ilyenformán a pszichopatológiák kialakulásának és fennmaradásának valószínúségét e kétféle hálózati típus aránya együttesen jelöli ki.

\section{EGY ESETTANULMÁNY TANULSÁGAI}

Az alábbi szakaszban egy kényszerbetegséggel küzdő amerikai páciensről készült esettanulmány segítségével illusztrálom a fenti összefüggéseket (Oltmans et al. 2012: 1-15). Minthogy maga az esettanulmány a dolgozattól független, saját szempontok szerint készült, így nem teszi lehetővé a különböző hálózati logikák átfogó feltérképezését. Arra ugyanakkor lehetőséget kínál, hogy a benne előforduló hálózattípusokon keresztül bemutatásra kerüljön a kényszerbetegségek és a kognitív terápiák hálózati modellje.

Karen 30 éves, 4 gyermekes, háztartásbeli családanya, a '70-es években, egy amerikai nagyvárosban él. Azért fordult pszichológushoz, mert egyrészt kontrollálhatatlan módon, irracionális mértékben aggódott gyer- 
mekei egészségéért, másrészt szokásává vált a környezetében megjelenő véletlenszerű számokból következtetéseket levonni a gyerekeket fenyegető veszélyek valószínúségére. Így például úgy érezte, hogy nem gyújthat rá csupán egy cigarettára, hanem csak négyre, különben veszélybe sodorja a három további cigaretta által szimbolizált gyermeket. Amennyiben az ehhez hasonló rítusokat elmulasztotta - annak ellenére, hogy irracionális mivoltukkal tisztában volt -, elviselhetetlen szorongást érzett, különösen, hogy az előbb-utóbb óhatatlanul bekövetkező soron következő apróbb baleseteket saját mulasztásával magyarázta. A kényszeres gondolatok és viselkedésmintázatok mellett Karen beszámolt arról is, hogy házasságával és a gyerekekkel való viszonyával egyaránt elégedetlen: szívproblémák miatt leszázalékolt férje csak feküdt otthon egész nap, és elvárta, hogy kiszolgálják, anélkül hogy bármiben is segített volna, a gyerekek semmibe vették szülői tekintélyét és kezelhetetlenek voltak.

Karenről kiderült továbbá, hogy rendkívül szigorú, rideg, vallásos családban nőtt fel, ahol a katolikus rítusokat dogmatikusan követték. Elsőáldozásakor lelkére kötötték, hogy minden búnét meg kell gyónnia, különben üdvözülését kockáztatja. Miután, ennek ellenére, kisgyermekként mégsem mert bevallani egy apró lopást, később sokáig erős bűntudat gyötörte, ami rémálmokban és szorongásban jutott kifejeződésre. Ezt később az egyházi rítusok minél szigorúbb betartásával próbálta ellensúlyozni, amik ily módon hétköznapi viselkedésének szervezőelvévé váltak. Korán házasodott, és hamar teherbe is esett, ekkor - egy szemtanúként látott gyerekbaleset hatására - kezdődtek a gyermekei iránti irracionális aggodalmak. Az esetleges bántódásukra vonatkozó egyre gyakoribb riasztó gondolatokat semlegesítendő, kezdetben rövid imát mormolt el, ami sokáig hatékonynak is bizonyult, különösen hogy a gyerekek körüli teendők egyébként is maximálisan lekötötték figyelmét.

Az egyházi tradíciók idóközben - a második vatikáni zsinat reformjainak hatására - egyre inkább fellazultak, így Karen fokozatosan elidegenedett saját vallásosságától, hiszen épp azt nem volt képes nyújtani, amire szüksége lett volna: megkérdőjelezhetetlen érvényességú rítusokat. Így amikor a második gyermek születése után kiköltöztek a külvárosba, nem csupán az addig kialakított baráti kapcsolatai szakadtak meg, hanem egyúttal arra sem volt már képes, hogy az új egyházi közösségbe beintegrálódjon. Annak ellenére, hogy ily módon fokozatosan izolálódott, egyfajta boldogtalan egyensúly állt be Karen életébe: férjétól, aki értelmetlennek látta Karen azon törekvését, hogy szülei szigorú nevelési klímáját reprodukálja, fokozatosan eltávolodott, azonban a gyerekek érdekében együtt maradtak, felosztva a családi feladatokat és felelősségeket. Ez a törékeny egyensúly borult fel a férj leszázalékolásával, aminek hatására a korábban kordában tartott aggodalmak, valamint a - hiteltelenné vált egyházi rítusok helyét átvevő - kényszeres számmisztika elhatalmasodtak Karenen.

A terapeuta elsősorban arra törekedett, hogy Karen számára megteremtse a saját élete feletti kontroll lehetőségét. A kényszeres gondolatokat és viselkedésmintákat fenntartó kontrollálhatatlan élethelyzet megváltoztatásával ugyanis egyúttal a kontroll illúzióját biztosító privát rítusok iránti igény is megszűnik. E célból a terápia során különböző technikák kerültek párhuzamosan alkalmazásra. Egyrészt a férjjel való viszonyt rendezendő, asszertív tréningre került sor, melynek során azok a maladaptív automatikus gondolatok (pl. mindenkinek szeretnie kell őt és ezért soha nem konfrontálódhat) kerültek lebontásra, melyek akadályozták az önérvényesítést. Másrészt pedagógiai tanácsadást kapott a gyerekekkel való viszony javulását elősegítendő. Harmadrészt a privát rítusok helyett a terapeuta arra bíztatta, hogy próbáljon meg az egyházi rítusokhoz visszatérni, felkeresve 
egy konzervatívabb papot. Végül az ily módon lecsökkent kényszeres gondolatok és viselkedésminták további ritkítására olyan kognitív-behaviorista technikát ajánlott, ami részben a szorongás irracionális mivoltát tárja fel, részben a szorongást okozó élmény felidézése mellett a rögzült válaszreakció kiiktatásával operál (Oltmans et al. 2012: 1-15).

Karen kényszerbetegségének kialakulását társadalomelméleti szempontból úgy értelmezhetjük, mint a torzult hálózati konfigurációk arányának megnövekedését. A gyerekkori szocializációt mindenekelőtt a szülők szigorú vallásosságában kifejeződő dogmatikus életvilág jellemezte. Ez kiegészült egy rideg érzelmi klímával, ami egyfelől a szülői szeretet torzulását, másfelől a kommunikatív cselekvés elidegenedését fejezi ki. E megterhelő hálózati konfigurációk hatását ugyanakkor sokáig ellensúlyozni tudja az egyházi intézményrendszer formáját öltő posztintencionális rendszer. Ily módon sajátos egyensúlyi állapot stabilizálódik: a torzult hálózatokra történő reflexióra ugyan nincs mód, és ennek hatására jelentősen beszúkül Karen mozgástere, ugyanakkor a belőlük fakadó érzelmi feszültség csökkentésére lehetőséget kínálnak az egyházi rítusok, melyek stabil és ebben az értelemben kiismerhető, belakható normatív kereteket jelölnek ki a hétköznapi cselekvések számára.

A különböző hálózati logikák lehetőségtere segítségével mindenekelőtt világossá lehet tenni, hogy mik azok a kötéstípusok, melyekből Karen kimarad. Egyrészt azáltal, hogy háztartásbeliként a munkaerő-piacra nem lép be, a mezők, rendszerek és reflexív intézmények szférájához kevés kapcsolódási pontja akad, továbbá a megbecsülésen alapuló hálózatok is blokkolódnak számára. Ezzel összefüggésben a kognitív, interszubjektív és esztétikai reflexivitás hálózatai is hiányoznak életéből, melyek hiánya korlátozott adaptív potenciált eredményez. Az olyan ijesztő lehetőségek, mint a gyermekre leselkedő veszélyek, a posztintencionális hálózatokhoz való kapcsolódás hiányában kizárólagossá válnak és felnagyítódnak; az önbizalom és önbecsülés hiányában az elhárításukhoz szükséges magabiztosság hiányzik; reflexivitás híján pedig a konstruktív megoldások keresésének útjai blokkolódnak. Egyéb alternatíva híján Karen a rendelkezésére álló hálózati keretek között oldja meg problémáit: a dogmatikus rítusokkal való extrém azonosulással.

Ez azonban annak ellenére, hogy a belső feszültséget csökkenteni tudja, pragmatikus szempontból diszfunkcionális. Az olyan új feladatok, mint a saját családon belüli társas viszonyok kölcsönösen kielégítő kereteinek megteremtése, megfelelő gyermekkori tapasztalatok, önbizalom és reflexivitás együttes hiányában kudarcba fulladnak. Így Karen saját családján belül önkéntelenül is reprodukálja azt a szeretet és a kommunikatív cselekvés torzulásával terhelt hálózati konstellációt, melynek maga is áldozata. Ebben a részben beszűkült, részben a meglévő hálózatokon belül a torzulások magas arányával terhelt interakciós közegben a kényszerbetegségek kialakulásának kockázata önmagában is magas. Akkor azonban, amikor ez az érzékeny egyensúly is felborul, a kockázat realizálódik.

A hálózatok átrendeződésének első mozzanata az addig feszültségcsökkentésre használt egyházi intézményi hálózatról való lekapcsolódás volt. Ahogy a korábban rendszerszerűen működő és ebben az értelemben világos, megkérdőjelezhetetlen viselkedésformát kikényszerítő hálózat reflexív intézménnyé alakult át, úgy lehetetlenült el a hozzá való kapcsolódás Karen számára. A rendszerszerú intézménnyel szemben ugyanis, a reflexív intézmények reflexív cselekvőt feltételeznek, mely kompetencia hiánya blokkolja a hozzájuk való kapcsolódást. Azáltal, hogy az intézmény által biztosított társadalmi rítusok nem voltak többé hozzáférhetők, Karen arra 
kényszerült, hogy olyan privát, eltitkolt rutinokat fejlesszen ki, melyek utat nyitnak a kényszerbetegség irányába. A hálózatok egyensúlyi átrendeződésének másik mozzanata a férj otthonmaradásához köthető. Ezáltal ugyanis egy olyan elem súlya nőtt meg drasztikusan Karen kapcsolathálózatán belül, akihez több szempontból is torzult kötésekkel kapcsolódott. A férjjel folytatott, elsősorban a - főként kiszolgálásra irányuló - interakciók folyamatossá válása egyrészt az intimitás hiányára hívta fel a figyelmet, másrészt a kommunikáció elidegenültségét fejezte ki, harmadrészt a megbecsülés hiányát emelte ki, negyedrészt a közös munkamegosztás illúziójának érvénytelenné válását tette nyilvánvalóvá. Ezek a korábban háttérbe szorított torzulások súlya, a férj hálózati pozíciójának transzformációja következtében hirtelen megnőtt.

E két hatás eredményeként Karen kapcsolathálózatán belül csaknem kirázólagossá váltak azok a torzult kapcsolódások, melyek elviselhetetlen, ugyanakkor megszüntethetetlen feszültséggel megterhelve őt, végül kényszeres gondolatok és viselkedésformák kialakulásához vezettek. A nem kizárólag kognitív eszközökre támaszkodó terápia e hálózati konstelláció megváltoztatására törekedett. Maga a terápiás viszony egy olyan hálózatként értelmezhető, ami Karen számára lehetőséget teremtett a kommunikativ cselekvésre és a szakértői tudásokon alapuló reflexióra. A terápiás hálózat perspektivájából mindenekelőtt lehetőség nyílik a korábbi torzult kommunikációs, reflexív és elismerési viszonyok átértékelésére. Ezáltal elsősorban a férj otthon maradása miatt hangsúlyossá váló többszörösen torzult kapcsolódás korrekciójára nyilik lehetőség, részben a torzult önbecsülés helyreállítása, részben az interakció új formáira való ösztönzés révén. A terapeuta továbbá javasolja olyan hálózatoknak a felújitását, melyek az egyház „leleplezett illúzióját” helyreállíthatják, és a feszültségcsökkentést az eltitkolt babonák helyett a nyilvánosan vállalható rítusok pályájára visszaterelik. Ily módon a korábban felborult hálózati egyensúly helyreállítható: a torzult elemek torzulása korrigálható, és arányuk az összes hálózaton belül csökkenthető.

Amellett, hogy e hálózati átalakulások az esettanulmány szerint jelentősen javították Karen állapotát, a kritikai hálózatelmélet perspektivájából a terápia hiányaira is rámutathatunk. Minthogy az eredeti problémát a kapcsolathálózat beszúkülése és torzulása okozta, ezért valójában annak feloldása is csak a kötések kiterjesztése és minőségének javításától várható. A terápia mindezekhez a feladatokhoz ugyanakkor csak részlegesen fért hozzá. Minthogy csak a fennálló kapcsolatok perspektivájában gondolkodik, így nem fér hozzá sem a kapcsolódások tágabb lehetőségteréhez, sem pedig a kapcsolathálózatok közti kölcsönhatásokhoz. Így egyrészt nem reflektál arra, hogy milyen következményei vannak a - munkaerőpiacról való távolmaradásból fakadóan - a posztintencionális hálózatok széles köréhez való kapcsolódás blokkolásának. E hálózatok nem csupán abból a szempontból kitüntetett jelentőségűek, hogy a kötések számának növelésével lehetőséget teremtenek a torzult kötések arányának csökkentésére, hanem abból a szempontból is, hogy potenciális terepei mind az egyéni és kommunikatív reflexivitásnak, mind pedig a megbecsülésnek. Másrészt nem veszi észre azt sem, hogy a javasolt változtatások inkonzisztensek abban az értelemben, hogy egyrészt a reflexivitás növelésére irányulnak, másrészt egy merev intézményhez (konzervatív egyházi közösség) való kapcsolódásra ösztönöznek. Minthogy e kétféle hálózati logika egymást kölcsönösen kizárja, így hosszútávon egyik vagy másik destabilizálódása valószínúsíthető. 
Végül a terápia nem reflektál saját pontszerúségéből fakadó korlátaira sem: a kényszerbetegség újbóli kialakulásának kockázata elsősorban azzal csökkenthető, ha a cselekvő olyan komplementer hálózatokhoz kapcsolódik hozzá, melyek hatásukban imitálják a torzult kötéseket kezelő terápiákat. Az elidegenedett kognitív és interszubjektív reflexivitás esetében - a 3. táblázat alapján - ez azt jelenti, hogy a gondolkodást és kommunikációt társadalmi gyakorlatokhoz kötő illúzión, az önálló és társas reflexióhoz szükséges önbecsülést megerősítő szolidaritáson, a gondolkodást újraalapozó esztétikai reflexivitáson alapuló hálózatokhoz való kapcsolódásra van szükség. A teljesítmény méltánytalan értékelése esetében pedig a teljesítmény alternatív dimenzióit feltáró illúzión, a teljesítmény méltányos kereteit kijelölő szakértői tudáson, a megbecsülés kereteit interaktívan megújító kommunikatív cselekvésen, a megbecsüléstől való függetlenedést lehetővé tevő esztétikai reflexivitáson alapuló hálózatokhoz való kapcsolódásra. Csakis attól várható a reflexivitás és önbecsülés tartós korrekciója, ami egyúttal a saját élet feletti kontroll és a kényszerbetegség elhárításának előfeltétele is, ha az ezt valószínúsítő hálózatok stabil alkotóelemeivé válnak az egyén kapcsolathálózatának.

A fenti példa a kritikai elméletek számára elsősorban azzal a tanulsággal szolgál, hogy bemutatja, miként kapcsolódhatnak egymáshoz különböző torzult hálózati konfigurációk, és hogy kizárólagossá válva miként eredményezik kényszerbetegség kialakulását és fennmaradását. Az esettanulmányból jól látható e folyamat hálózati dinamikája, melynek kezdőpontja a torzult hálózati konfigurációk kialakulása és lehetséges kapcsolódások körének beszűkülése, folytatása a torzult hálózati konfigurációk kizárólagossá válása, végül feloldása a torzulások feloldására tett kísérlet és a kapcsolódások terének kibővítése. A kritikai hálózatelmélet célja az ehhez hasonló dinamikák azonosítása és detektálása társadalmi szinten.

\section{ZÁRÓ MEGJEGYZÉSEK}

A kényszerbetegségek és kognitiv terápia hálózatelméleti újraértelmezése csupán a szenvedés határállapotainak és a szenvedés enyhítésére kidolgozott praxisnak egy-egy példájaként értelmezhető. A szenvedés tapasztalatából közvetlenül kiinduló kritikai elméletnek arra kell törekednie, hogy a különböző határállapotok (kényszerbetegségek mellett ilyen még a generalizált szorongás, fóbiák, pánik és stressz-zavarok, függőségek, hangulatzavarok, szomatoform zavarok, skizofrénia, disszociatív zavarok és személyiségzavarok) és terápiás praxisok (a kognitív terápia mellett ezek a pszichoanalitikus, behaviorista, személyközpontú és a családi vagy társadalmi viszonyokra fókuszáló megközelítések) lehető legtágabb listájából induljon ki. Egy ilyen elmélet, azonosítva a preintencionális, intencionális és posztintencionális hálózatok torzulásait, valamint a torzulást különböző szinteken kezelni tudó terápiás hálózati konfigurációkat, egyszerre egyesíti a korábbi kritikai elméletek integrációs modelljeit és teremt lehetőséget a szenvedés közvetlen tapasztalatából kiinduló társadalomkritikára.

A különböző kritikai elméletek társadalmi integrációra vonatkozó modelljeinek szintéziséből csupán korlátozott mértékben következtethetünk analitikusan az azok perspektívájából feltáruló emancipatorikus és patologikus tendenciák közti kölcsönhatásokra. ${ }^{7}$ E korlátot feloldandó, a különböző integrációs modelleket egyesítő kritikai elmélet normatív bázisának kidolgozásakor, az egyes elméletek értékvonatkoztatásának szintézise he-

7 Máshol erre több kísérletet is tettem (Sik 2012: 267-309, Sik 2015b). Részben az ezek során tapasztalt korlátok ösztönöztek egy olyan elmélet kialakítására, ami csupán társadalomelméleti szinten integrálja a rendelkezésre álló integrációs modelleket, miközben a kordiagnózis szintjén önálló empirikus bázisra támaszkodik. 
lyett az elméletektől független szempontokból kell kiindulni. A szenvedés pszichiátriai és pszichológiai tekintet számára feltáruló határállapotai ilyen társadalomelméleti és filozófiai antropológiai modellektől független tapasztalatokat fejeznek ki. E tapasztalatok révén olyan nyitott elmélethez jutunk, ami egyrészt tetszőlegesen bővíthető a pszichopatológiákra vonatkozó pszichiátriai és pszichológiai tudással, másrészt bővíthető a társadalmi integrációra vonatkozó újabb és újabb elméletekkel. Ebben az értelemben folyamatosan képes mind a szenvedés új tapasztalatait, mind pedig a társadalmi integráció új formáit becsatornázni az elméletalkotás folyamatába. Egyedül egy ilyen értelemben kétszeresen is nyitott elmélet rejti magában a lehetőségét annak, hogy a társadalomkritika szenvedés és integráció folyamatosan változó formáira egyaránt reagálni tudjon.

A hálózati megközelítés a kritika számára tág kereteket jelöl ki. Egyrészt magában rejti a lokális hálózatok és élethelyzetek elemzésének lehetőségét, ezáltal szempontokat kínálva a cselekvő központú kritika - és potenciálisan a terápiás gyakorlatok - számára. Másrészt lehetővé teszi a társadalmi hálózatok egymáshoz kapcsolódásának elemzését és ezáltal megnyitja az utat a kordiagnózisok kidolgozása számára: azok a társulások, melyekben a különböző szinten szerveződő hálózatok patologikus konfigurációi kapcsolódnak egymáshoz, miközben a patológia csökkentésének esélyét magában hordozó hálózatok blokkolva vannak, továbbá azok a hálózatszerveződési dinamikák, melyek a patologikus konfigurációk sűrúsödését és ezzel párhuzamosan a terápiás hálózatok ritkulását eredményezik, egyaránt a társadalomkritika tárgyává tehetők. 


\section{HIVATKOZÁSOK}

APA (2013) Diagnostic and Statistical Manual of Mental Disorders - $5^{\text {th }}$ edition (DSM 5). American Psychiatric Association, Washington DC: American Psychiatric Publishing. http://dx.doi.org/10.1176/appi.books.9780890425596.

Adorno, Th. (1973) Negative Dialectics. Trans. E. B. Ashton, New York: Seabury Press. http://dx.doi.org/10.4324/9780203479605.

Beck, A. T. (1975) Cognitive therapy and the emotional disorders. Madison, CT: International Universities Press. http://dx.doi.org/10.1007/978-1-4684-2496-6_5.

Bourdieu, P. (2002) A gyakorlati észjárás: a társadalmi cselekvés elméletéröl. Ford. Berkovits B. Budapest: Napvilág.

Bugarszki Zs. (2003) A szociális munka új lehetőségei a pszichiátriai betegek ellátásában Esély, 1, 67-86.

Comer, R. J. (2010) Abnormal Psychology - $7^{\text {th }}$ edition. New York: Worth Publishers.

Fernezely B. - Légmán A. (2003) A skizofrénia társadalmi narrativái. Esély, 6, 39-57.

Foucault, M. (1999) A szexualitás története: a tudás akarása. Ford. Ádám P. Budapest: Atlantisz.

Foucault, M. (2004) A bolondság története. Budapest: Atlantisz.

Giddens, A. (1984) The Constitution of Society. Outline of the Theory of Structuration. Cambridge: Polity.

Giddens, A. (1991) Modernity and Self-Identity. Self and Society in the Late Modern Age. Cambridge: Polity.

Goffman, E. (1974) Asylums: essays on the social situation of mental patients and other. Harmondsworth: Penguin Books.

Habermas, J. (2005) Megismerés és érdek. Pécs: Jelenkor.

Habermas, J. (2011) A kommunikativ cselekvés elmélete. Budapest: Gondolat.

Honneth, A. (2013) Harc az elismerésért. Budapest: L'Harmattan.

Laing, R. D. (1990) Bölcsek, balgák, bolondok. Budapest: Európa.

Lash, S. (1999) Another Modernity. A Different Rationality. Oxford: Blackwell.

Lash, S. (2002) Critique of Information. London: Sage. http://dx.doi.org/10.4135/9781446217283.

Oltmans, Th. F. - Martin, M. T. - Neale, J. M. - Davison, G. C. (2012) Case Studies in Abnormal Psychology - 9th Edition. Wiley. Schütz, A. - Luckmann, Th. (1974) The structures of the life-world. (Trans. Zaner, R. M. - Engelhardt, H. T.). London, Heinemann. Sharf, R. S. (2012) Theories of Psychotherapy and Counseling $-5^{\text {th }}$ edition. Concepts and Cases. Belmont CA: Brooks/ Cole.

Stein, L. - Santos, A. (1998) Assertive Community Treatment of Persons with Severe Mental Illness. New York-London: Norton and Co. Sik D. (2012) A modernizáció ingája - Egy genetikus kritikai elmélet vázlata. Budapest: ELTE - Eötvös.

Sik D. (2014) A klasszikus és késő modernitás egyesített elmélete. Socio.hu, 4, 150-181. http://dx.doi.org/10.18030/socio.hu.2014.4.150.

Sik D. (2015a) Towards a network based critical theory (kézirat).

Sik D. (2015b) Klasszikus és késő modernitás a rendszerváltás utáni Magyarországon. Socio.hu, 1. http://dx.doi.org/10.18030/socio.hu.2015.1.246.

Szasz, Th. (2002) Az elmebetegség mítosza. Budapest: Akadémiai. 